\title{
LEVEL II SCOUR ANALYSIS FOR BRIDGE 15 (BOLTTH00150015) on TOWN HIGHWAY 15, crossing JOINER BROOK, BOLTON, VERMONT
}

Open-File Report 98-425

Prepared in cooperation with

VERMONT AGENCY OF TRANSPORTATION

and

FEDERAL HIGHWAY ADMINISTRATION

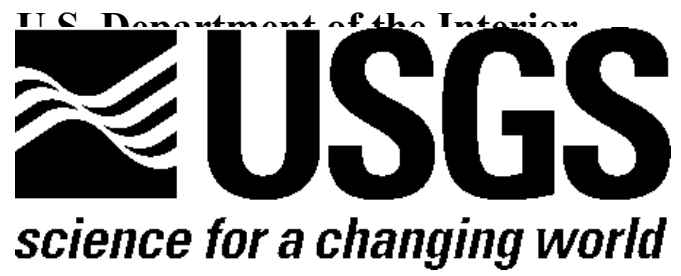




\section{LEVEL II SCOUR ANALYSIS FOR BRIDGE 15 (BOLTTH00150015) on TOWN HIGHWAY 15, crossing JOINER BROOK, BOLTON, VERMONT \\ By RONDA L. BURNS and EMILY C. WILD}

U.S. Geological Survey Open-File Report 98-425

Prepared in cooperation with

VERMONT AGENCY OF TRANSPORTATION

and

FEDERAL HIGHWAY ADMINISTRATION 


\title{
U.S. DEPARTMENT OF THE INTERIOR BRUCE BABBITT, Secretary
}

\author{
U.S. GEOLOGICAL SURVEY
}

Thomas J. Casadevall, Acting Director

For additional information write to:

District Chief

U.S. Geological Survey 361 Commerce Way

Pembroke, NH 03275-3718
Copies of this report may be purchased from:

U.S. Geological Survey

Branch of Information Services

Open-File Reports Unit

Box 25286

Denver, CO 80225-0286 


\section{CONTENTS}

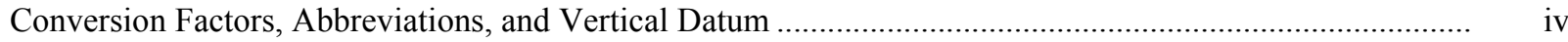

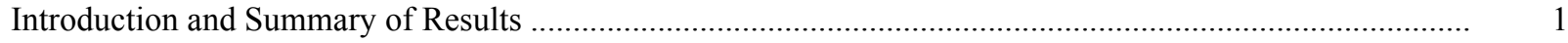

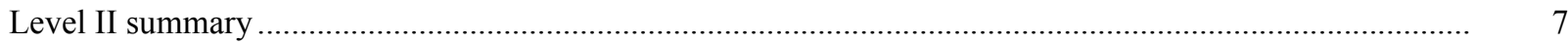

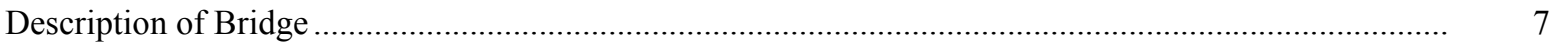

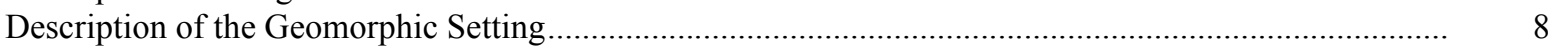

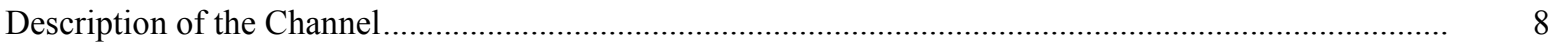

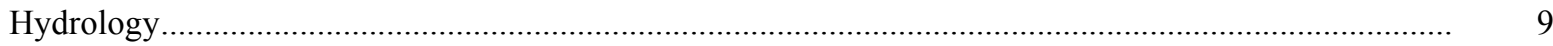

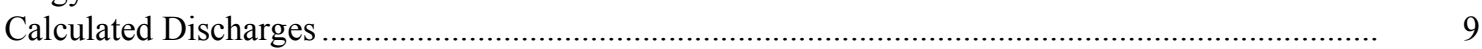

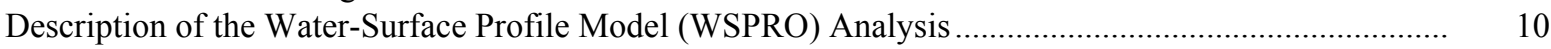

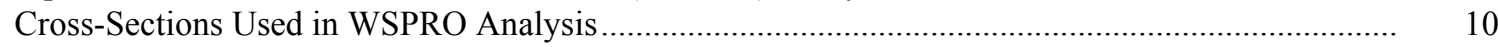

Data and Assumptions Used in WSPRO Model ........................................................................ 11

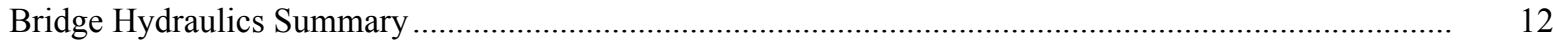

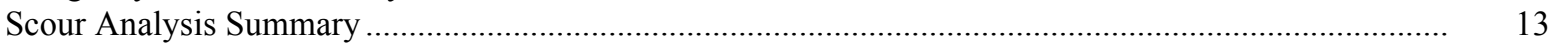

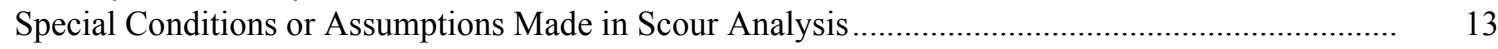

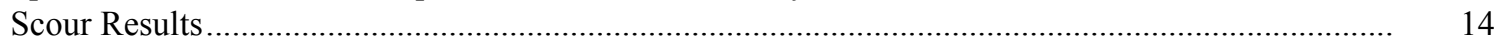

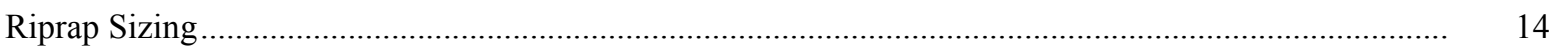

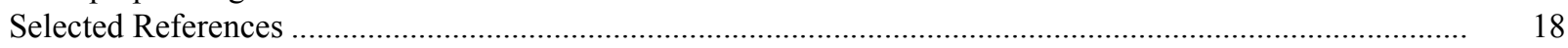

Appendices:

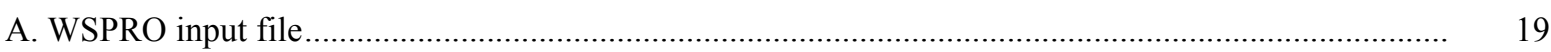

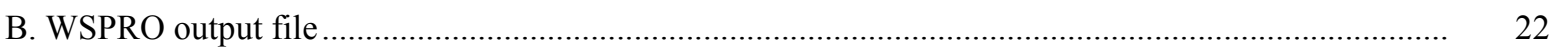

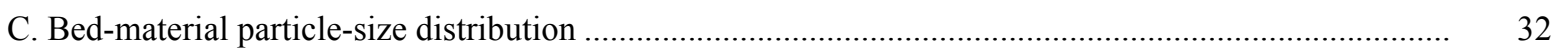

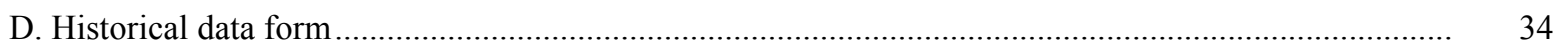

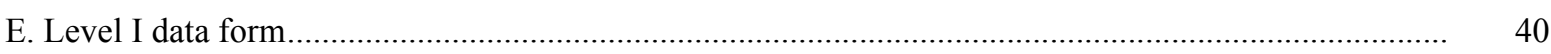

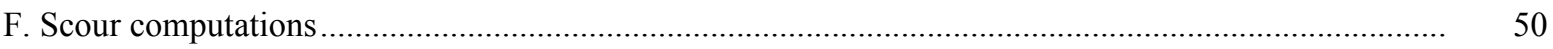

\section{FIGURES}

1. Map showing location of study area on four USGS 1:24,000 scale maps.

2. Map showing location of study area on Vermont Agency of Transportation town highway map .....

3. Structure BOLTTH00150015 viewed from upstream (June 27, 1996) ...

4. Downstream channel viewed from structure BOLTTH00150015 (June 27, 1996)

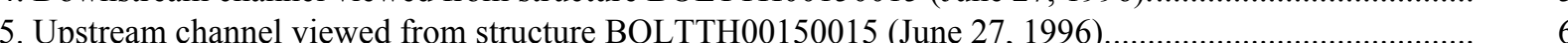

6. Structure BOLTTH00150015 viewed from downstream (June 27, 1996).

7. Water-surface profiles for the 100- and 500-year discharges at structure

BOLTTH00150015 on Town Highway 15, crossing Joiner Brook,

Bolton, Vermont.

8. Scour elevations for the 100- and 500-year discharges at structure

BOLTTH00150015 on Town Highway 15, crossing Joiner Brook,

Bolton, Vermont.

\section{TABLES}

1. Remaining footing/pile depth at abutments for the 100-year discharge at structure

BOLTTH00150015 on Town Highway 15, crossing Joiner Brook,

Bolton, Vermont.

2. Remaining footing/pile depth at abutments for the 500-year discharge at structure

BOLTTH00150015 on Town Highway 15, crossing Joiner Brook,

Bolton, Vermont. 


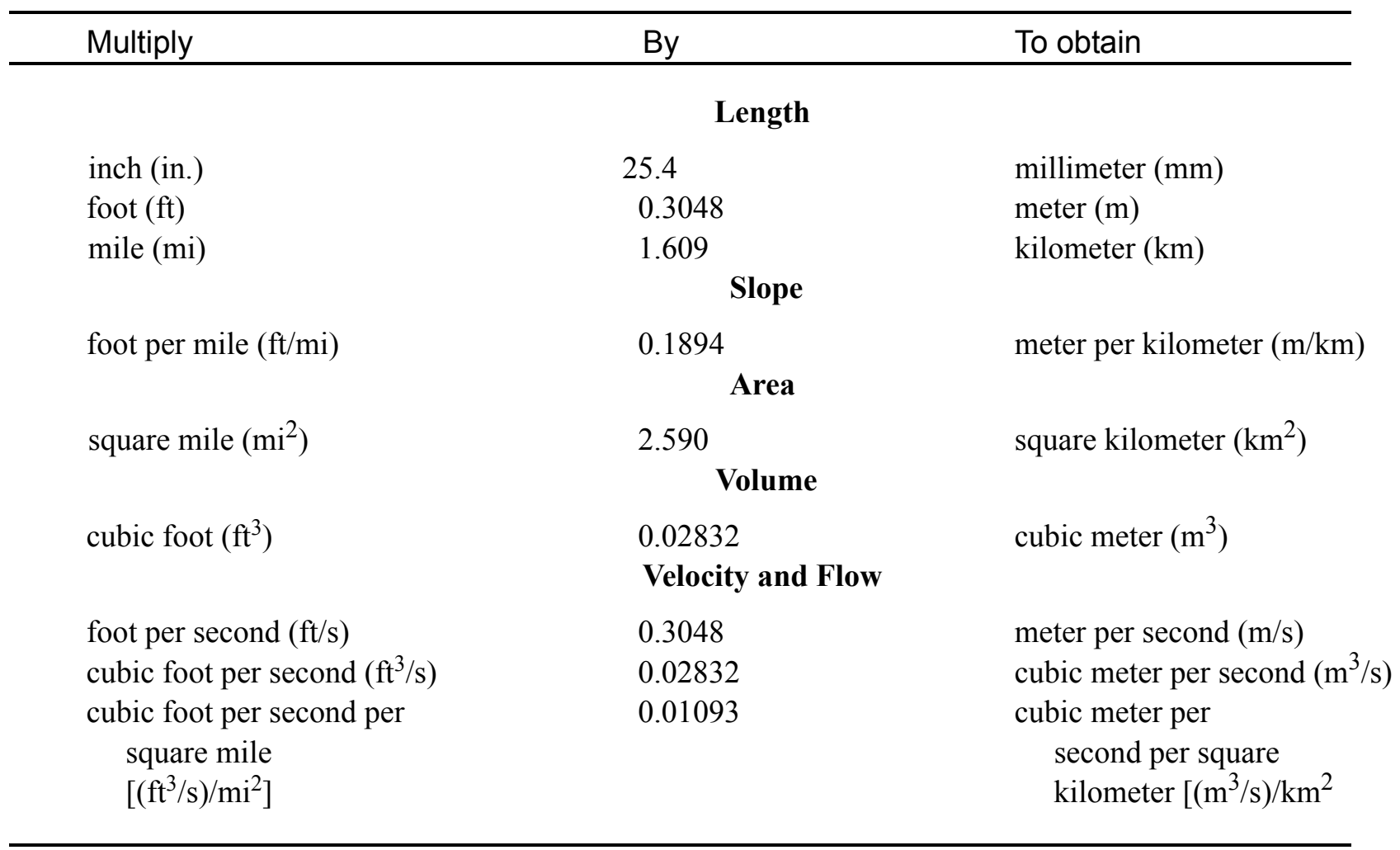

\section{OTHER ABBREVIATIONS}

$\begin{array}{lrlr}\mathrm{BF} & \text { bank full } & \text { LWW } & \text { left wingwall } \\ \mathrm{cfs} & \text { cubic feet per second } & \text { Max } & \text { maximum } \\ \mathrm{D}_{50} & \text { median diameter of bed material } & \text { MC } & \text { main channel } \\ \mathrm{DS} & \text { downstream } & \text { RAB } & \text { right abutment } \\ \mathrm{elev} & \text { elevation } & \text { RABUT } & \text { face of right abutment } \\ \mathrm{f} / \mathrm{p} & \text { flood plain } & \text { RB } & \text { right bank } \\ \mathrm{ft} & \text { square feet } & \text { ROB } & \text { right overbank } \\ \mathrm{ft} / \mathrm{ft} & \text { feet per foot } & \text { RWW } & \text { right wingwall } \\ \mathrm{FEMA} & \text { Federal Emergency Management Agency } & \text { TH } & \text { town highway } \\ \mathrm{FHWA} & \text { Federal Highway Administration } & \text { UB } & \text { under bridge } \\ \mathrm{JCT} & \text { junction } & \text { US } & \text { upstream } \\ \text { LAB } & \text { left abutment } & \text { USGS } & \text { United States Geological Survey } \\ \text { LABUT } & \text { face of left abutment } & \text { VTAOT } & \text { Vermont Agency of Transportation } \\ \text { LB } & \text { left bank } & \text { WSPRO } & \text { water-surface profile model } \\ \text { LOB } & \text { left overbank } & \text { yr } & \text { year }\end{array}$

In this report, the words "right" and "left" refer to directions that would be reported by an observer facing downstream. Sea level: In this report, "sea level" refers to the National Geodetic Vertical Datum of 1929-- a geodetic datum derived from a general adjustment of the first-order level nets of the United States and Canada, formerly called Sea Level Datum of 1929.

In the appendices, the above abbreviations may be combined. For example, USLB would represent upstream left bank. 


\title{
LEVEL II SCOUR ANALYSIS FOR BRIDGE 15 (BOLTTH00150015) ON TOWN HIGHWAY 15, CROSSING JOINER BROOK, BOLTON, VERMONT
}

\author{
By Ronda L. Burns and Emily C. Wild
}

\section{INTRODUCTION AND SUMMARY OF RESULTS}

This report provides the results of a detailed Level II analysis of scour potential at structure BOLTTH00150015 on Town Highway 15 crossing Joiner Brook, Bolton, Vermont (figures 1-8). A Level II study is a basic engineering analysis of the site, including a quantitative analysis of stream stability and scour (FHWA, 1993). Results of a Level I scour investigation also are included in appendix $\mathrm{E}$ of this report. A Level I investigation provides a qualitative geomorphic characterization of the study site. Information on the bridge, gleaned from Vermont Agency of Transportation (VTAOT) files, was compiled prior to conducting Level I and Level II analyses and is found in appendix D.

The site is in the Green Mountain section of the New England physiographic province in north central Vermont. The $9.6-\mathrm{mi}^{2}$ drainage area is in a predominantly rural and forested basin. In the vicinity of the study site, the surface cover is pasture (lawn) downstream of the bridge and on the upstream right bank. The surface cover on the upstream left bank is shrub and brushland.

In the study area, Joiner Brook has an incised, straight channel with a slope of approximately $0.01 \mathrm{ft} / \mathrm{ft}$, an average channel top width of $61 \mathrm{ft}$ and an average bank height of $7 \mathrm{ft}$. The channel bed material ranges from gravel to cobble with a median grain size $\left(\mathrm{D}_{50}\right)$ of $43.6 \mathrm{~mm}(0.143 \mathrm{ft})$. The geomorphic assessment at the time of the Level I and Level II site visit on June 27, 1996, indicated that the reach was stable.

The Town Highway 15 crossing of Joiner Brook is a 39-ft-long, two-lane bridge consisting of one 36-foot concrete tee-beam span (Vermont Agency of Transportation, written communication, November 3,1995). The opening length of the structure parallel to the bridge face is $34.6 \mathrm{ft}$. The bridge is supported by nearly vertical, concrete abutments with wingwalls. The channel is skewed approximately 10 degrees to the opening while the opening-skew-to-roadway is zero degrees. 
A scour hole $1.5 \mathrm{ft}$ deeper than the mean thalweg depth was observed at the downstream end of the right abutment and along the downstream right wingwall during the Level I assessment. A second scour hole $1.2 \mathrm{ft}$ deeper than the mean thalweg depth was observed at the upstream end of the left abutment and along the upstream left wingwall. The left abutment footing is exposed in the area of the scour hole. Scour protection measures at the site included type-1 stone fill (less than 12 inches diameter) at the upstream end of the upstream left wingwall and at the downstream end of the downstream right wingwall and type-2 stone fill (less than 36 inches diameter) along the downstream left bank. There is also type-3 stone fill (less than 48 inches diameter) along the upstream left and right banks. Additional details describing conditions at the site are included in the Level II Summary and appendices $\mathrm{D}$ and $\mathrm{E}$.

Scour depths and recommended rock rip-rap sizes were computed using the general guidelines described in Hydraulic Engineering Circular 18 (Richardson and Davis, 1995) for the 100- and 500-year discharges. In addition, the incipient roadway-overtopping discharge was determined and analyzed as another potential worst-case scour scenario. Total scour at a highway crossing is comprised of three components: 1) long-term streambed degradation; 2) contraction scour (due to accelerated flow caused by a reduction in flow area at a bridge) and; 3 ) local scour (caused by accelerated flow around piers and abutments). Total scour is the sum of the three components. Equations are available to compute depths for contraction and local scour and a summary of the results of these computations follows.

Contraction scour for all modelled flows ranged from 0.8 to $3.5 \mathrm{ft}$. The worst-case contraction scour occurred at the 500-year discharge. Abutment scour ranged from 6.9 to $15.1 \mathrm{ft}$. The worst-case abutment scour occurred at the incipient roadway-overtopping discharge. Additional information on scour depths and depths to armoring are included in the section titled "Scour Results." Scoured-streambed elevations, based on the calculated scour depths, are presented in tables 1 and 2. A cross-section of the scour computed at the bridge is presented in figure 8 . Scour depths were calculated assuming an infinite depth of erosive material and a homogeneous particle-size distribution.

It is generally accepted that the Froehlich equation (abutment scour) gives "excessively conservative estimates of scour depths" (Richardson and Davis, 1995, p. 46). Usually, computed scour depths are evaluated in combination with other information including (but not limited to) historical performance during flood events, the geomorphic stability assessment, existing scour protection measures, and the results of the hydraulic analyses. Therefore, scour depths adopted by VTAOT may differ from the computed values documented herein. 


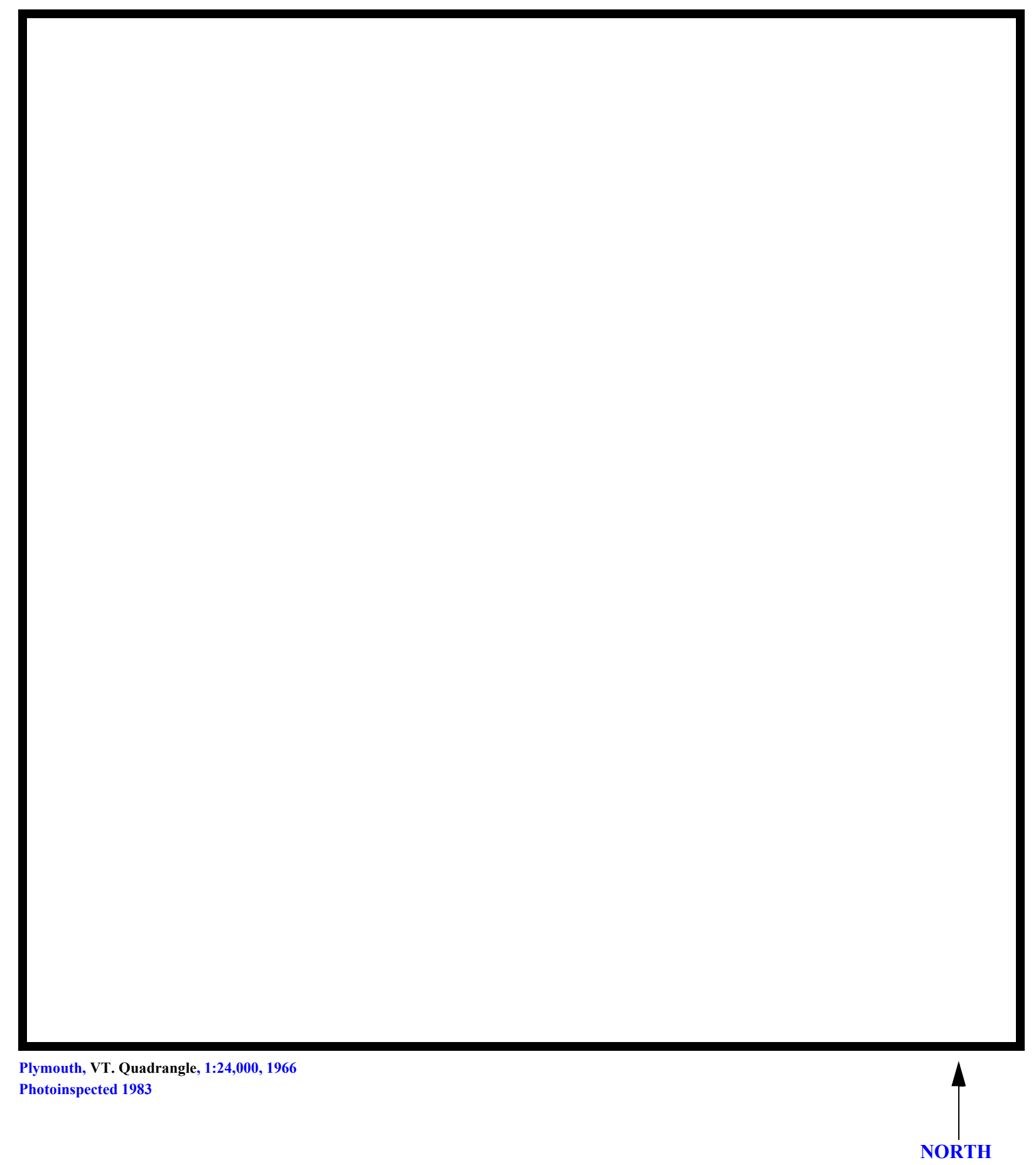

Figure 1. Location of study area on USGS 1:24,000 scale map. 
Figure 2. Location of study area on Vermont Agency of Transportation town highway map. 

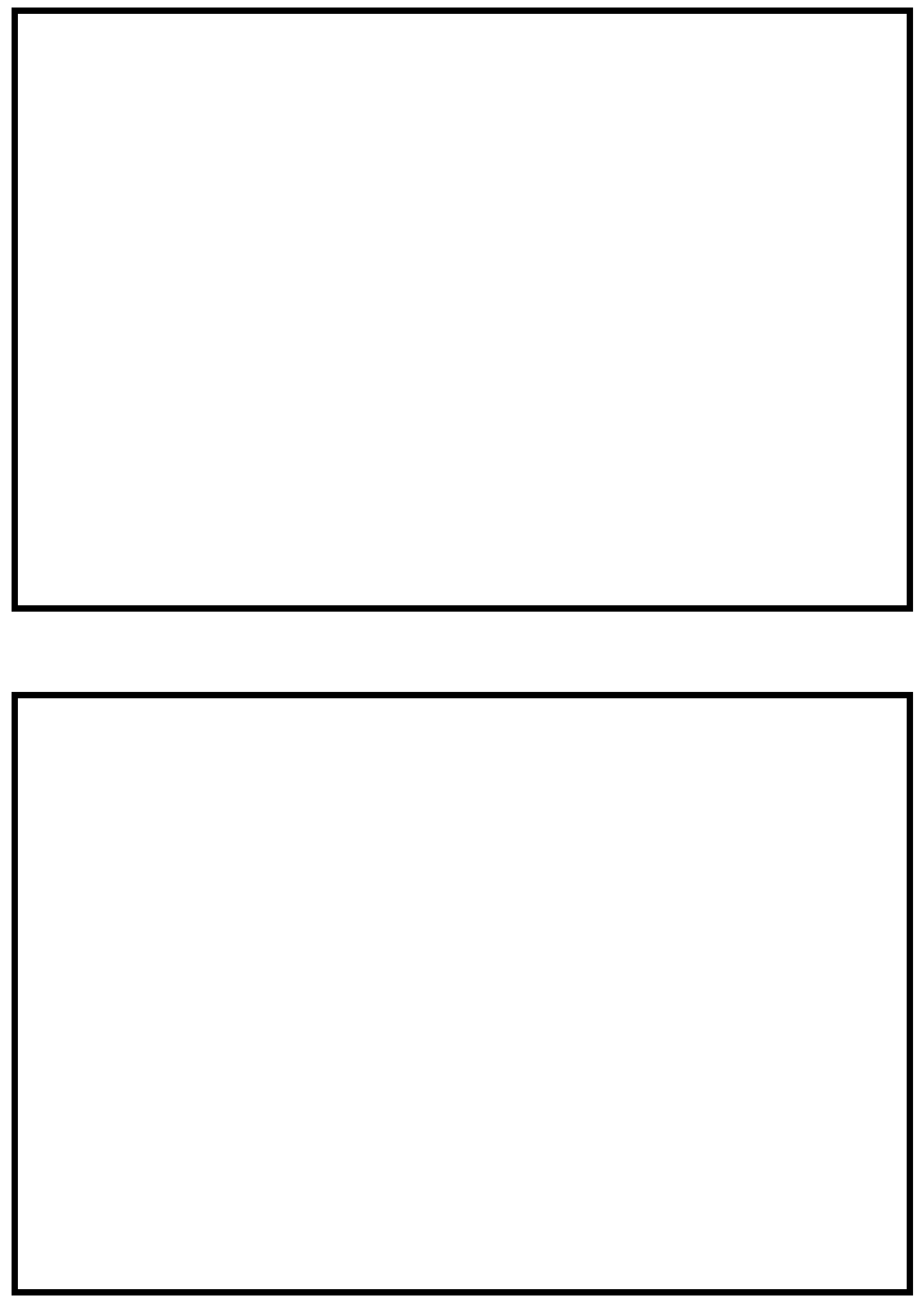

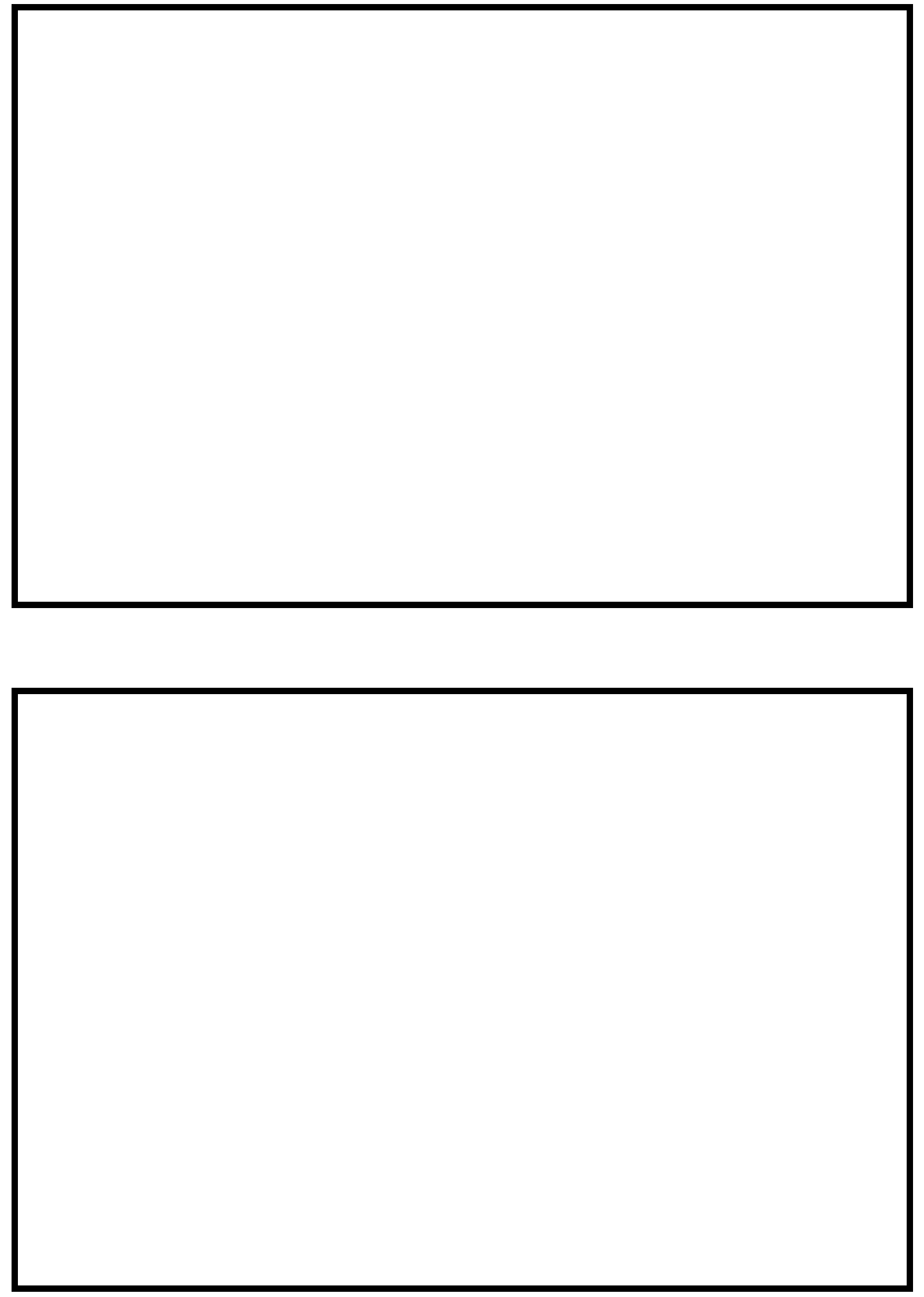


\section{LEVEL II SUMMARY}

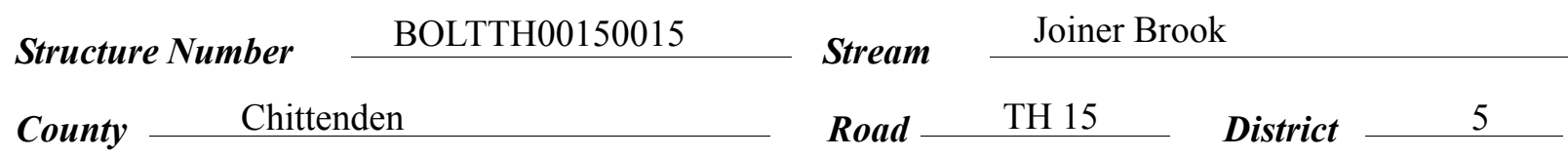

\section{Description of Bridge}

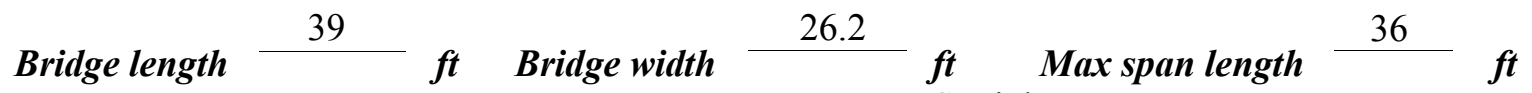
Alignment of bridge to road (on curve or straight)

Abutment type Vertical, concrete

Stone fill on abutment?

$$
\text { Yes }
$$

\section{Embankment type} Straight

\section{namanimtinn af atans fill} Maro af insnortinn
Type-1, at the upstream end of the upstream left wingwall and at the downstream end of the downstream right wingwall.

Abutments and wingwalls are concrete. There is a 1.2-ft

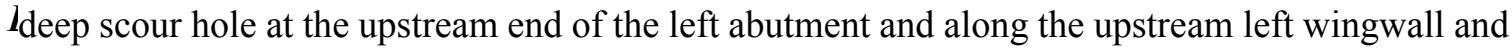
a 1.5-ft deep scour hole at the downstream end of the right abutment and along the downstream right wingwall.

$$
\text { Yes }
$$

Is bridge skewed to flood flow according to Yes ' survey?

Angle

There is a moderate channel bend through the bridge, The scour holes have developed in the locations where the bridge constricts the flow.

\begin{tabular}{|c|c|c|}
\hline $\begin{array}{c}\text { Date af insnortion } \\
6 / 27 / 96\end{array}$ & $\begin{array}{l}\text { Percent of rhmmal } \\
\text { bloeked hortzontatly }\end{array}$ & $\begin{array}{l}\text { Percent of } \\
\text { blocked verticatty }\end{array}$ \\
\hline & 0 & 0 \\
\hline
\end{tabular}

Debris accumulation on bridge at time of Level I or Level II site visit:

Level II Moderate. Some debris is caught along the banks upstream.

\section{Potential for debris}

None were observed on 6/27/96.

Dosriho anv, foaturos noar ar at tho hridoo that mav affort flow, (includo ahsorvation dato) 


\section{Description of the Geomorphic Setting}

General topography The channel is located in a high relief valley.

Geomorphic conditions at bridge site: downstream (DS), upstream (US)

Date of inspection $\quad 6 / 27 / 96$

DS left: $\quad$ Steep channel bank to an irregular overbank

DS right: $\quad$ Steep channel bank to an irregular overbank

US left: $\quad$ Steep road embankment for I-89

US right: $\quad$ Steep channel bank to an irregular overbank

\section{Description of the Channel}

\begin{tabular}{|c|c|c|c|}
\hline \multirow[b]{2}{*}{ Average top width } & 61 & \multirow[b]{2}{*}{ Average depth } & \multirow[b]{2}{*}{ Sand/Gravel ${ }^{\boldsymbol{f}}$} \\
\hline & $\stackrel{\boldsymbol{f t}}{\text { Gravel/Cobbles }}$ & & \\
\hline \multicolumn{2}{|c|}{ Predominant bed material } & Bank material & Perennial and straight \\
\hline
\end{tabular}

$6 / 27 / 96$

Vegetative co ${ }^{1}$ Few trees and brush with grass on the overbank

DS left: $\quad$ Few trees and brush with grass on the overbank

DS right: $\quad$ Few trees, shrubs, and brush

US left: $\quad$ Few trees and brush with grass on the overbank

US right: $\quad$ Yes

Do banks appear stable? -

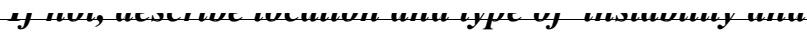

date of observatton.

According to the

assessment of 6/27/96 a railroad bridge was observed about $190 \mathrm{ft}$ downstream from this bridge. Describe any obstructions in channel and date of observation. 


\title{
Hydrology
}

Drainage area $\frac{9.60}{m^{2}}{ }^{2}$

Percentage of drainage area in physiographic provinces: (approximate)

Physiographic province/section

New England/Green Mountain
Percent of drainage area 100

\begin{abstract}
Is drainage area considered rural or urban? Rural Describe any significant urbanization: None
\end{abstract}

Is there a

Is there a USGS gage on the stream of interest? $--$

USGS gage description

USGS gage number

Gage drainage area $\mathrm{mi}^{2}$ No

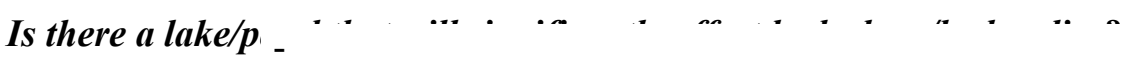

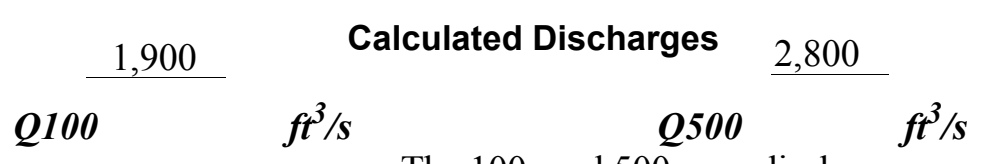

The 100- and 500-year discharges are the median

values of the range defined by flood frequency curves developed from several empirical methods (Benson, 1962; Johnson and Tasker, 1974; FHWA, 1983; Potter, 1957a\&b; Talbot, 1887). Each curve was extended graphically to the 500 -year event. 


\section{Description of the Water-Surface Profile Model (WSPRO) Analysis}

Datum for WSPRO analysis (USGS survey, sea level, VTAOT plans)

USGS survey

Datum tie between USGS survey and VTAOT plans

None

Description of reference marks used to determine USGS datum.

$\mathrm{RM} 1$ is a chiseled $\mathrm{X}$ on

top of the upstream end of the left abutment (elev. $499.29 \mathrm{ft}$, arbitrary survey datum). RM2 is a

chiseled X on top of the downstream right end of the bridge curb (elev. $500.73 \mathrm{ft}$, arbitrary

survey datum). RM3 is a nail, $5.1 \mathrm{ft}$ above the ground, in an utility pole located $100 \mathrm{ft}$ to the left

of the left bank and $15 \mathrm{ft}$ downstream from the road (elev. $504.41 \mathrm{ft}$, arbitrary survey datum).

\begin{tabular}{|c|c|c|c|}
\hline${ }^{1}$ Cross-section & $\begin{array}{c}\text { Section } \\
\text { Reference } \\
\text { Distance } \\
\text { (SRD) in feet }\end{array}$ & $\begin{array}{c}{ }^{2} \text { Cross-section } \\
\text { development }\end{array}$ & Comments \\
\hline EXTRR & -242 & 1 & $\begin{array}{l}\text { Railroad bridge Exit sec- } \\
\text { tion }\end{array}$ \\
\hline FLVRR & -188 & 2 & $\begin{array}{l}\text { Railroad bridge Full-val- } \\
\text { ley section (Templated } \\
\text { from EXTRR) }\end{array}$ \\
\hline RRBRG & -188 & 1 & Railroad bridge section \\
\hline RRBED & -176 & 1 & Railroad Grade section \\
\hline APPRR & -110 & 3 & $\begin{array}{l}\text { Railroad bridge Approach } \\
\text { section (Modified from } \\
\text { EXITX) }\end{array}$ \\
\hline EXITX & -27 & 1 & Exit section \\
\hline FULLV & 0 & 2 & $\begin{array}{l}\text { Downstream Full-valley } \\
\text { section (Templated from } \\
\text { EXITX) }\end{array}$ \\
\hline BRIDG & 0 & 1 & Bridge section \\
\hline RDWAY & 14 & 1 & Road Grade section \\
\hline APPRO & 63 & 1 & Approach section \\
\hline
\end{tabular}

${ }^{1}$ For location of cross-sections see plan-view sketch included with Level I field form, appendix E.

For more detail on how cross-sections were developed see WSPRO input file. 


\section{Data and Assumptions Used in WSPRO Model}

Hydraulic analyses of the reach were done by use of the Federal Highway Administration's WSPRO step-backwater computer program (Shearman and others, 1986, and Shearman, 1990). The analyses reported herein reflect conditions existing at the site at the time of the study. Furthermore, in the development of the model it was necessary to assume no accumulation of debris or ice at the site. Results of the hydraulic model are presented in the Bridge Hydraulic Summary, appendix B, and figure 7.

Channel roughness factors (Manning's " $n$ ") used in the hydraulic model were estimated using field inspections at each cross section following the general guidelines described by Arcement and Schneider (1989). Final adjustments to the values were made during the modelling of the reach. Channel " $n$ " values for the reach ranged from 0.035 to 0.066 , and overbank " $n$ " values ranged from 0.035 to 0.070 .

Normal depth at the railroad bridge exit section (EXTRR) was assumed as the starting water surface. This depth was computed by use of the slope-conveyance method outlined in the user's manual for WSPRO (Shearman, 1990). The slope used was $0.0099 \mathrm{ft} / \mathrm{ft}$, which was estimated from thalweg points surveyed downstream of the bridge.

The surveyed approach section (APPRO) was modelled one bridge length upstream of the upstream face as recommended by Shearman and others (1986). This location provides a consistent method for determining scour variables. 


\section{Bridge Hydraulics Summary}

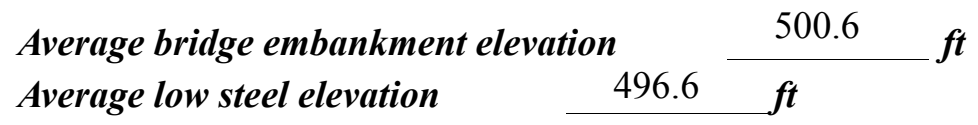

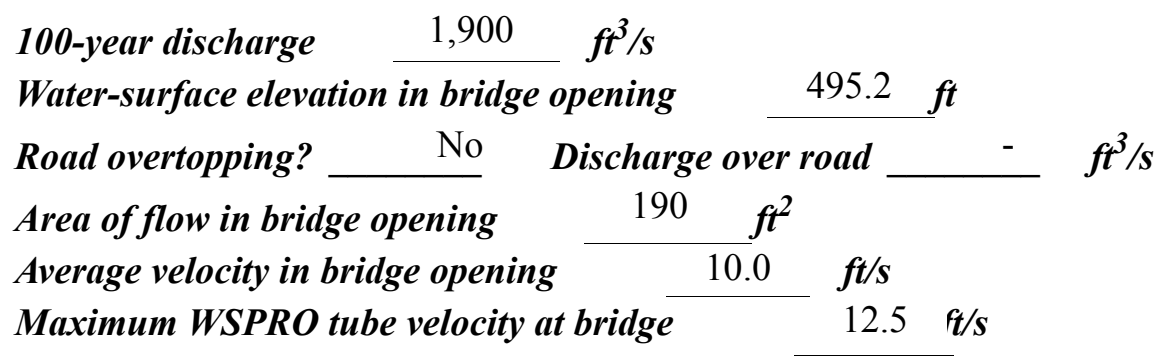

Water-surface elevation at Approach section with bridge

496.7

Water-surface elevation at Approach section without bridge

Amount of backwater caused by bridge

0.2 it

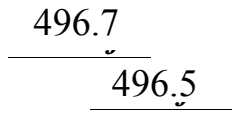

500-year discharge $\quad 2,800 \quad \mathrm{ft}^{3} / \mathrm{s}$

Water-surface elevation in bridge opening $496.6 \mathrm{ft}$

Road overtopping? ___ Yes Discharge over road __ $188 \quad \mathrm{i}^{3} / \mathrm{s}$

Area of flow in bridge opening $\quad 236 \quad \mathrm{ft}^{2}$

Average velocity in bridge opening $11.3 \mathrm{ft} / \mathrm{s}$

Maximum WSPRO tube velocity at bridge 13.5 's

Water-surface elevation at Approach section with bridge 500.2

Water-surface elevation at Approach section without bridge $\quad 497.3$

Amount of backwater caused by bridge $\quad 2.9, t$

Incipient overtopping discharge $\quad 2,560 \mathrm{ft}^{3} / \mathrm{s}$

Water-surface elevation in bridge opening $496.6 \quad t$

Area of flow in bridge opening $\quad 236 \quad \mathrm{ft}^{2}$

Average velocity in bridge opening $\quad 10.8 \quad \mathrm{ft} / \mathrm{s}$

Maximum WSPRO tube velocity at bridge $13.0 \mathrm{ft} / \mathrm{s}$

Water-surface elevation at Approach section with bridge

Water-surface elevation at Approach section without bridge

499.7

Amount of backwater caused by bridge $\quad 2.1$, t 


\section{Scour Analysis Summary}

\section{Special Conditions or Assumptions Made in Scour Analysis}

Scour depths were computed using the general guidelines described in Hydraulic Engineering Circular 18 (Richardson and Davis, 1995). Scour depths were calculated assuming an infinite depth of erosive material and a homogeneous particle-size distribution. The results of the scour analyses for the 100-and 500-year discharges are presented in tables 1 and 2 and the scour depths are shown graphically in figure 8 .

Contraction scour for the 100-year discharge was computed by use of the Laursen clear-water contraction scour equation (Richardson and Davis, 1995, p. 32, equation 20). At this site, the 500-year and incipient roadway-overtopping discharges resulted in submerged orifice flow. Contraction scour at bridges with orifice flow is best estimated by use of the Chang pressure-flow scour equation (oral communication, J. Sterling Jones, October 4, 1996). Thus, contraction scour for these discharges was computed by use of the Chang equation (Richardson and Davis, 1995, p. 145-146). The streambed armoring depths computed suggest that armoring will not limit the depth of contraction scour.

For comparison, contraction scour for the discharges resulting in orifice flow also was computed by use of the Laursen clear-water contraction scour equation and the Umbrell pressure-flow equation (Richardson and Davis, 1995, p. 144). Results from these computations are presented in appendix F.

Abutment scour was computed by use of the Froehlich equation (Richardson and Davis, 1995, p. 48, equation 28). Variables for the Froehlich equation include the Froude number of the flow approaching the embankments, the length of the embankment blocking flow, and the depth of flow approaching the embankment less any roadway overtopping. 


\section{Scour Results}

Contraction scour:

Main channel

Live-bed scour

Clear-water scour

Depth to armoring

Left overbank

Right overbank

Local scour:

Abutment scour

Left abutment

Right abutment

Pier scour

Pier 1

Pier 2

Pier 3 100-year
discharge 500-year discharge

(Scour depths in feet)
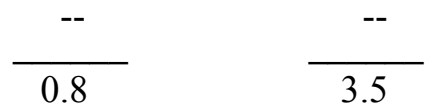

$10.9^{-}$

$22.2^{-}$
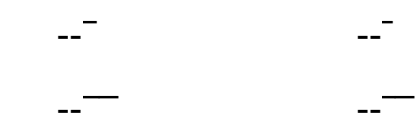

7.6

6.9

$14.4-$

9.2

9.9-

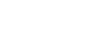
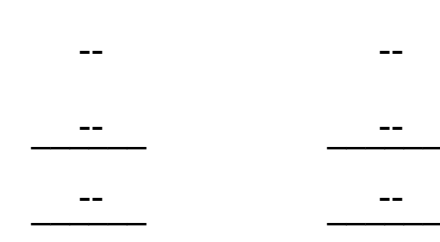

Incipient overtopping discharge 


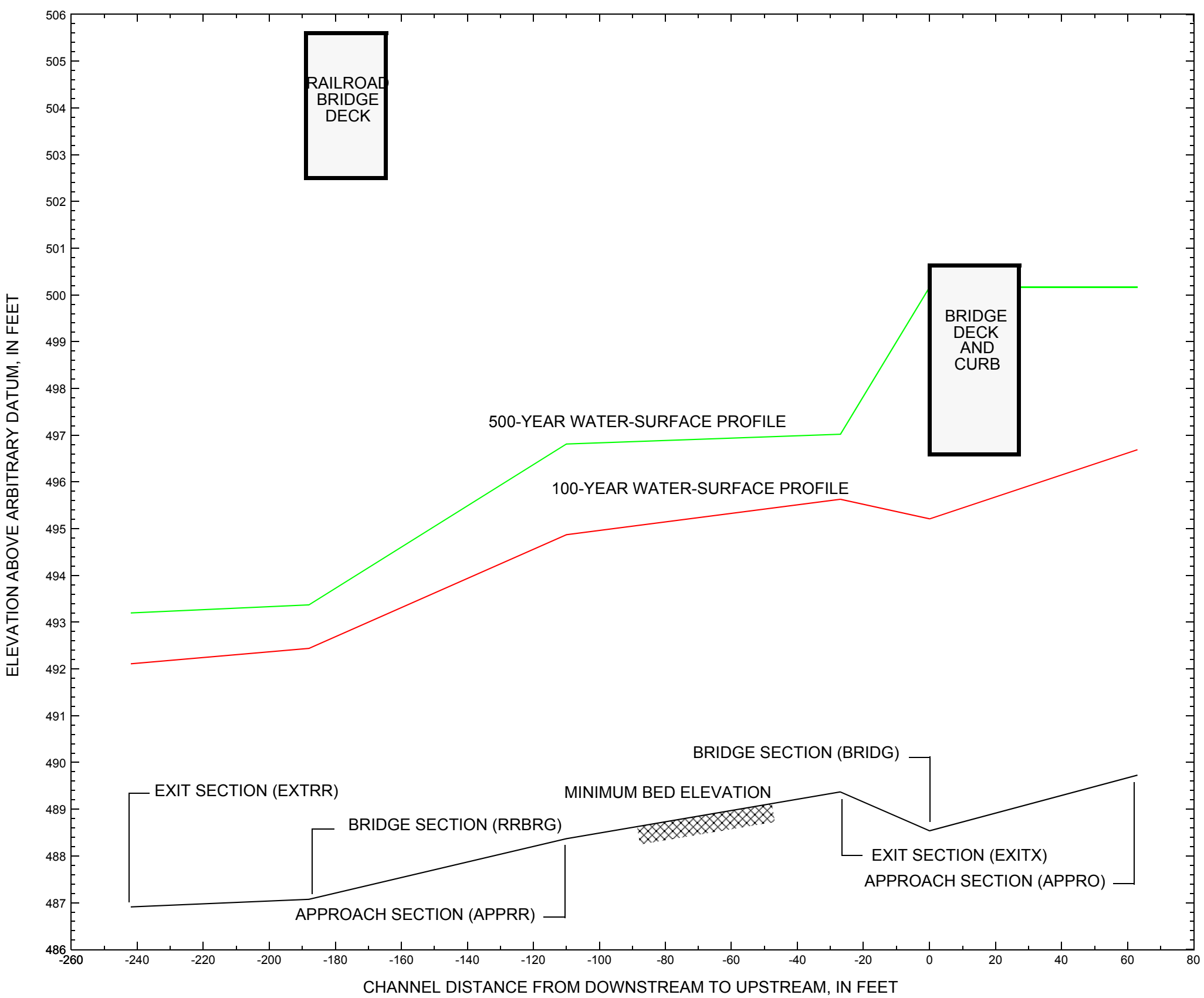

Figure 7. Water-surface profiles for the 100- and 500-year discharges at structure BOLTTH00150015 on Town Highway 15, crossing Joiner Brook, Bolton, Vermont. 


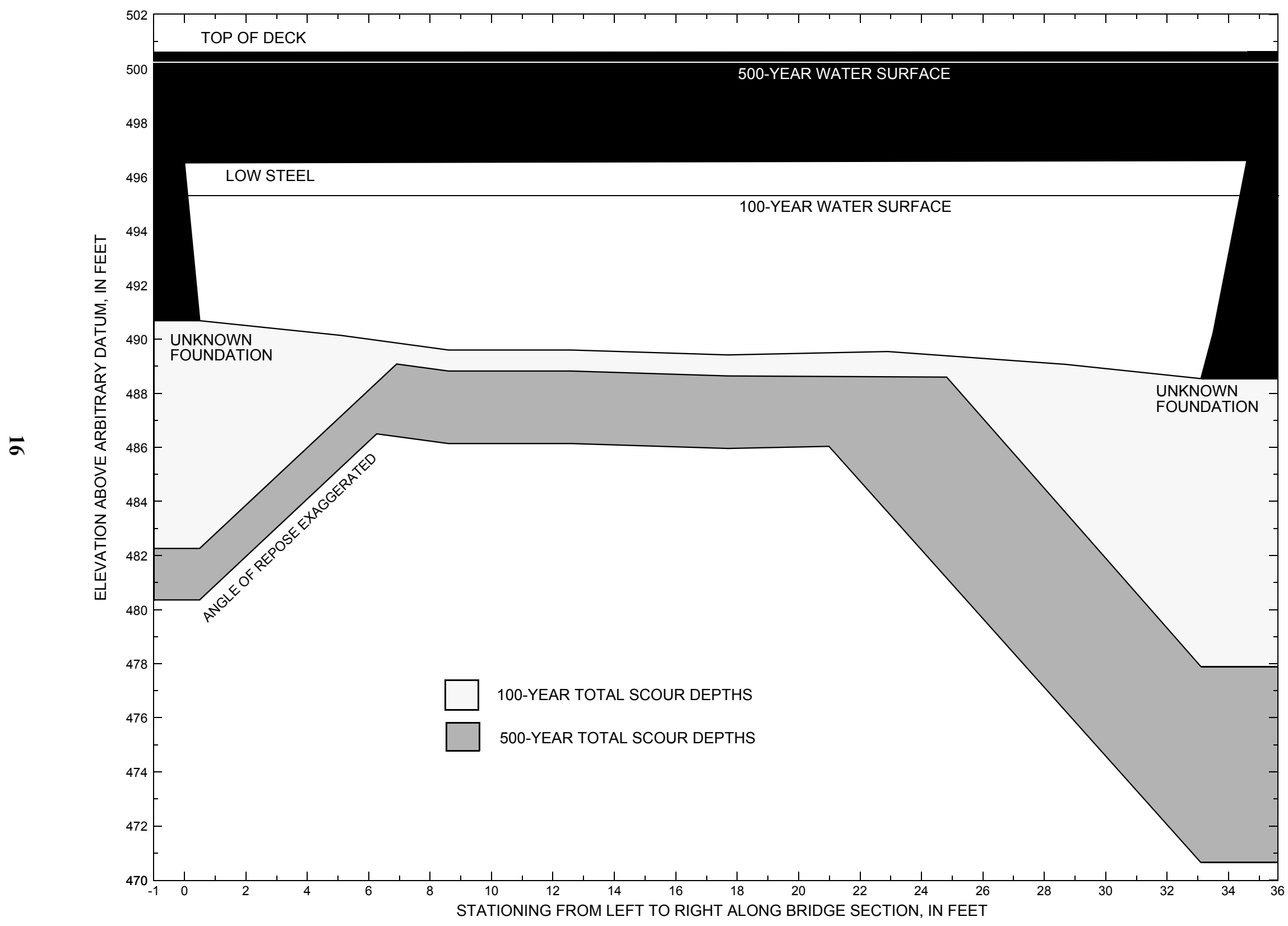

Figure 8. Scour elevations for the 100- and 500-year discharges at structure BOLTTH00150015 on Town Highway 15, crossing Joiner Brook, Bolton, Vermont. 
Table 1. Remaining footing/pile depth at abutments for the 100-year discharge at structure BOLTTH00150015 on Town Highway 15, crossing Joiner Brook, Bolton, Vermont. [VTAOT, Vermont Agency of Transportation; --, no data]

\begin{tabular}{|c|c|c|c|c|c|c|c|c|c|c|c|}
\hline Description & Station $^{1}$ & $\begin{array}{l}\text { VTAOT } \\
\text { minimum } \\
\text { low-chord } \\
\text { elevation } \\
\text { (feet) }\end{array}$ & $\begin{array}{l}\text { Surveyed } \\
\text { minimum } \\
\text { low-chord } \\
\text { elevation } \\
\text { (feet) }\end{array}$ & $\begin{array}{c}\text { Bottom of } \\
\text { footing/pile } \\
\text { elevation }{ }^{2} \\
\text { (feet) }\end{array}$ & $\begin{array}{c}\text { Channel } \\
\text { elevation at } \\
\text { abutment/ } \\
\text { pier }^{2} \\
\text { (feet) }\end{array}$ & $\begin{array}{l}\text { Contraction } \\
\text { scour depth } \\
\text { (feet) }\end{array}$ & $\begin{array}{l}\text { Abutment } \\
\text { scour } \\
\text { depth } \\
\text { (feet) }\end{array}$ & $\begin{array}{l}\text { Pier } \\
\text { scour } \\
\text { depth } \\
\text { (feet) }\end{array}$ & $\begin{array}{l}\text { Depth of } \\
\text { total scour } \\
\text { (feet) }\end{array}$ & $\begin{array}{c}\text { Elevation of } \\
\text { scour }^{2} \\
\text { (feet) }\end{array}$ & $\begin{array}{c}\text { Remaining } \\
\text { footing/pile } \\
\text { depth } \\
\text { (feet) }\end{array}$ \\
\hline \multicolumn{12}{|c|}{100 -year discharge is 1,900 cubic-feet per second } \\
\hline Left abutment & 0.0 & -- & 496.5 & -- & 490.7 & 0.8 & 7.6 & -- & 8.4 & 482.3 & -- \\
\hline Right abutment & 34.6 & -- & 496.6 & -- & 488.5 & 0.8 & 9.9 & -- & 10.7 & 477.8 & -- \\
\hline
\end{tabular}

1.Measured along the face of the most constricting side of the bridge.

2.Arbitrary datum for this study.

Table 2. Remaining footing/pile depth at abutments for the 500-year discharge at structure BOLTTH00150015 on Town Highway 15, crossing Joiner Brook, Bolton, Vermont. [VTAOT, Vermont Agency of Transportation; --, no data]

\begin{tabular}{|c|c|c|c|c|c|c|c|c|c|c|c|}
\hline Description & Station $^{1}$ & $\begin{array}{l}\text { VTAOT } \\
\text { minimum } \\
\text { low-chord } \\
\text { elevation } \\
\text { (feet) }\end{array}$ & $\begin{array}{l}\text { Surveyed } \\
\text { minimum } \\
\text { low-chord } \\
\text { elevation } \\
\text { (feet) }\end{array}$ & $\begin{array}{c}\text { Bottom of } \\
\text { footing/pile } \\
\text { elevation } \\
\text { (feet) }\end{array}$ & $\begin{array}{c}\text { Channel } \\
\text { elevation at } \\
\text { abutment/ } \\
\text { pier }^{2} \\
\text { (feet) }\end{array}$ & $\begin{array}{l}\text { Contraction } \\
\text { scour depth } \\
\text { (feet) }\end{array}$ & $\begin{array}{l}\text { Abutment } \\
\text { scour } \\
\text { depth } \\
\text { (feet) }\end{array}$ & $\begin{array}{l}\text { Pier } \\
\text { scour } \\
\text { depth } \\
\text { (feet) }\end{array}$ & $\begin{array}{l}\text { Depth of } \\
\text { total scour } \\
\text { (feet) }\end{array}$ & $\begin{array}{c}\text { Elevation of } \\
\text { scour }^{2} \\
\text { (feet) }\end{array}$ & $\begin{array}{c}\text { Remaining } \\
\text { footing/pile } \\
\text { depth } \\
\text { (feet) }\end{array}$ \\
\hline \multicolumn{12}{|c|}{500 -year discharge is 2,800 cubic-feet per second } \\
\hline Left abutment & 0.0 & -- & 496.5 & -- & 490.7 & 3.5 & 6.9 & -- & 10.4 & 480.3 & -- \\
\hline Right abutment & 34.6 & -- & 496.6 & -- & 488.5 & 3.5 & 14.4 & -- & 17.9 & 470.6 & -- \\
\hline
\end{tabular}

1.Measured along the face of the most constricting side of the bridge.

2.Arbitrary datum for this study. 


\section{SELECTED REFERENCES}

Arcement, G.J., Jr., and Schneider, V.R., 1989, Guide for selecting Manning's roughness coefficients for natural channels and flood plains: U.S. Geological Survey Water-Supply Paper 2339, 38 p.

Barnes, H.H., Jr., 1967, Roughness characteristics of natural channels: U.S. Geological Survey Water-Supply Paper 1849,213 p.

Benson, M. A., 1962, Factors Influencing the Occurrence of Floods in a Humid Region of Diverse Terrain: U.S. Geological Survey WaterSupply Paper 1580-B, 64 p.

Brown, S.A. and Clyde, E.S., 1989, Design of riprap revetment: Federal Highway Administration Hydraulic Engineering Circular No. 11, Publication FHWA-IP-89-016, 156 p.

Federal Highway Administration, 1983, Runoff estimates for small watersheds and development of sound design: Federal Highway Administration Report FHWA-RD-77-158.

Federal Highway Administration, 1993, Stream Stability and Scour at Highway Bridges: Participant Workbook: Federal Highway Administration Report FHWA-HI-91-011.

Froehlich, D.C., 1989, Local scour at bridge abutments in Ports, M.A., ed., Hydraulic Engineering--Proceedings of the 1989 National Conference on Hydraulic Engineering: New York, American Society of Civil Engineers, p. 13-18.

Hayes, D.C.,1993, Site selection and collection of bridge-scour data in Delaware, Maryland, and Virginia: U.S. Geological Survey WaterResources Investigation Report 93-4017, 23 p.

Interagency Advisory Committee on Water Data, 1982, Guidelines for determining flood flow frequency: U.S. Geological Survey, Bulletin 17B of the Hydrology Subcommittee, $190 \mathrm{p}$.

Johnson, C.G. and Tasker, G.D.,1974, Progress report on flood magnitude and frequency of Vermont streams: U.S. Geological Survey OpenFile Report 74-130, 37 p.

Lagasse, P.F., Schall, J.D., Johnson, F., Richardson, E.V., Chang, F., 1995, Stream Stability at Highway Structures: Federal Highway Administration Hydraulic Engineering Circular No. 20, Publication FHWA-IP-90-014, 144 p.

Laursen, E.M., 1960, Scour at bridge crossings: Journal of the Hydraulics Division, American Society of Civil Engineers, v. 86, no. HY2, p. 39-53.

Potter, W. D., 1957a, Peak rates of runoff in the Adirondack, White Mountains, and Maine woods area, Bureau of Public Roads

1957b, Peak rates of runoff in the New England Hill and Lowland area, Bureau of Public Roads

Richardson, E.V. and Davis, S.R., 1995, Evaluating scour at bridges: Federal Highway Administration Hydraulic Engineering Circular No. 18, Publication FHWA-IP-90-017, 204 p.

Richardson, E.V., Simons, D.B., and Julien, P.Y., 1990, Highways in the river environment: Federal Highway Administration Publication FHWA-HI-90-016.

Ritter, D.F., 1984, Process Geomorphology: W.C. Brown Co., Debuque, Iowa, 603 p.

Shearman, J.O., 1990, User's manual for WSPRO--a computer model for water surface profile computations: Federal Highway Administration Publication FHWA-IP-89-027, 187 p.

Shearman, J.O., Kirby, W.H., Schneider, V.R., and Flippo, H.N., 1986, Bridge waterways analysis model; research report: Federal Highway Administration Publication FHWA-RD-86-108, 112 p.

Talbot, A.N., 1887, The determination of water-way for bridges and culverts.

U.S. Geological Survey, 1948, Bolton Mountain, Vermont 7.5 Minute Series quadrangle map: U.S. Geological Survey Topographic Maps, Photoinspected 1983, Scale 1:24,000.

, 1948b, Huntington, Vermont 7.5 Minute Series quadrangle map: U.S. Geological Survey Topographic Maps, Photorevised 1980, Scale 1:24,000.

, 1948c, Richmond, Vermont 7.5 Minute Series quadrangle map: U.S. Geological Survey Topographic Maps, Photorevised 1980, Scale 1:24,000.

, 1948d, Waterbury, Vermont 7.5 Minute Series quadrangle map: U.S. Geological Survey Topographic Maps, Photorevised 1980, Scale 1:24,000. 


\section{APPENDIX A: \\ WSPRO INPUT FILE}




\section{WSPRO INPUT FILE}

GR

GR

GR

$\mathrm{N}$

SA

XS

BR

GR

GR

GR

GR

GR

GR

*

CD

$\mathrm{N}$

PW 1

PW 1

PW 1

*

*

$\mathrm{XR}$

GR

*

GR

GR

GR

GR

GR

GR

*

$\mathrm{N}$

SA

*
U.S. Geological Survey WSPRO Input File bolt015.wsp

Hydraulic analysis for structure BOLTTH00150015 Date: 24-FEB-98

TH 15 CROSSING JOINER BROOK IN BOLTON, VT

RLB

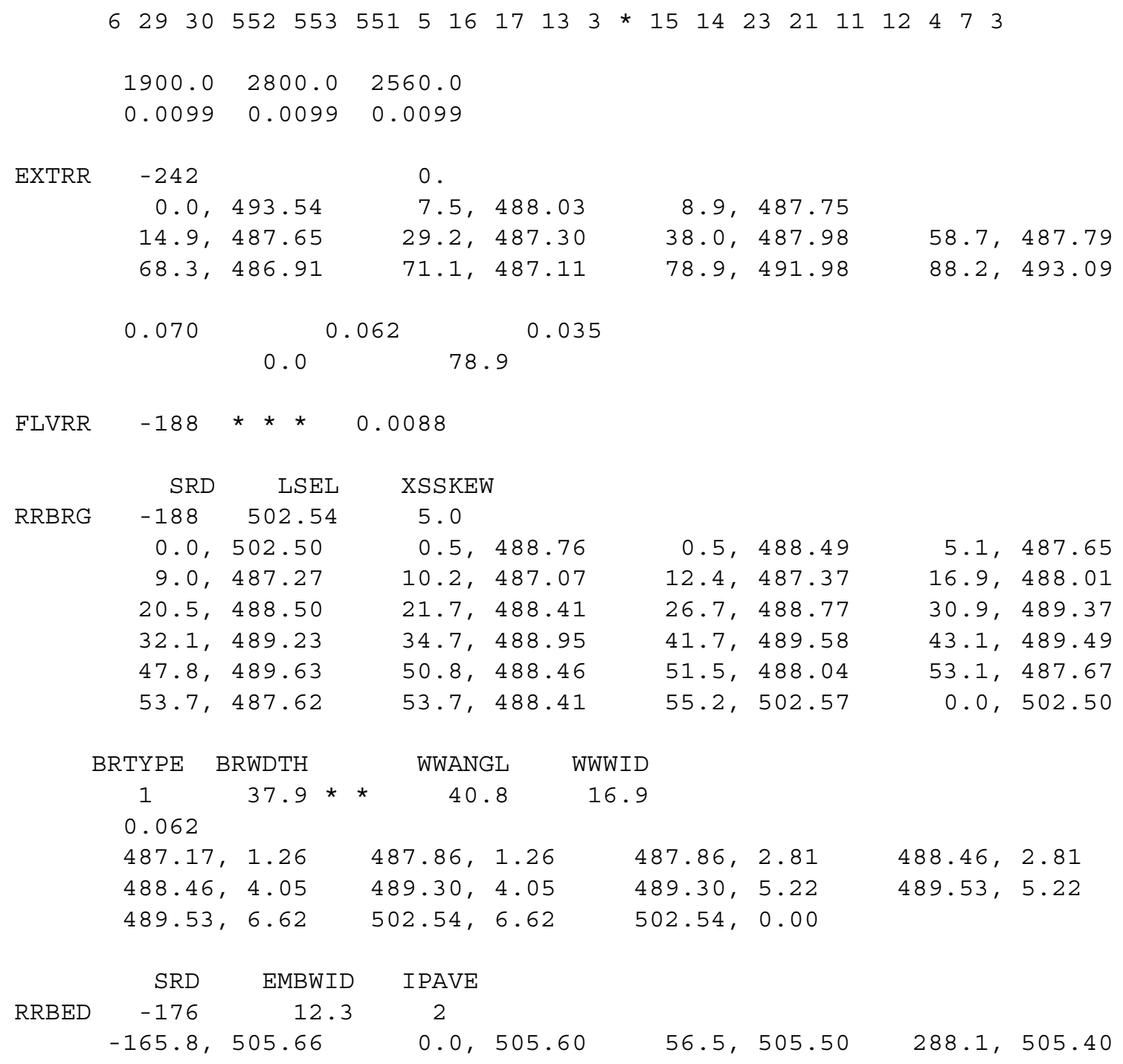


WSPRO INPUT FILE (continued)

\begin{tabular}{|c|c|c|c|c|c|c|c|}
\hline GR & & -176.4 & 505.64 & $-158.1,498.36$ & $-143.2,497.30$ & -84.4 & 497.77 \\
\hline GR & & -41.7 & 498.11 & $-13.5,497.04$ & $-6.1,492.68$ & 0.0 & 490.42 \\
\hline GR & & 5.0 & 490.19 & $12.9,489.55$ & $13.0,489.37$ & 19.1, & 489.44 \\
\hline GR & & 26.6, & 489.61 & $32.2,489.87$ & $37.3,490.18$ & 42.2, & 490.49 \\
\hline GR & & 45.3 & 493.99 & $49.6,497.87$ & & & \\
\hline $\begin{array}{l}\text { GR } \\
\star\end{array}$ & & $69.5,4$ & 495.42 & $111.6,493.6$ & $154.4,495.33$ & 171.6 & 499.93 \\
\hline $\mathrm{N}$ & & 0.035 & & 0.040 & & & \\
\hline $\begin{array}{l}\text { SA } \\
*\end{array}$ & & & -13.5 & 49.6 & & & \\
\hline $\begin{array}{l}\mathrm{XS} \\
\star\end{array}$ & FULLV & 0 & $\star \star * *$ & 0.0063 & & & \\
\hline * & & $\mathrm{SRD}$ & LSEL & XSSKEW & & & \\
\hline $\mathrm{BR}$ & BRIDG & 0 & 496.57 & 0.0 & & & \\
\hline GR & & 0.0 & 496.52 & $0.5,490.68$ & $5.1,490.14$ & 8.6, & 489.60 \\
\hline GR & & 12.6 & 489.60 & $17.7,489.42$ & $22.9,489.54$ & 28.7, & 489.07 \\
\hline $\begin{array}{l}\text { GR } \\
\star\end{array}$ & & 33.1, & 488.54 & $33.5,490.24$ & $34.6,496.61$ & 0.0 & 496.52 \\
\hline * & & BRTYPE & BRWDTH & WWANGL & & & \\
\hline$C D$ & & 1 & $40.8 *$ & 41.1 & .7 & & \\
\hline $\begin{array}{l}N \\
\star\end{array}$ & & 0.035 & & & & & \\
\hline * & & SRD & EMBWID & IPAVE & & & \\
\hline $\mathrm{XR}$ & RDWAY & 14 & 26.2 & 1 & & & \\
\hline GR & & -105.3 & 505.49 & $-92.3,501.67$ & $-35.5,499.99$ & -1.7 & 499.59 \\
\hline GR & & -1.6 & 500.56 & $0.0,500.61$ & $34.9,500.62$ & 36.4 & 500.62 \\
\hline GR & & 36.8 & 499.66 & $55.3,499.64$ & $126.9,499.99$ & 190.9, & 500.03 \\
\hline $\begin{array}{l}\text { GR } \\
*\end{array}$ & & 281.7 & 500.12 & $345.6,500.33$ & $401.6,502.05$ & 436.7 & 505.07 \\
\hline AS & APPRO & 63 & & 0 & & & \\
\hline GR & & -98.1 & 519.93 & $-60.6,502.20$ & $-32.7,500.11$ & -14.6 & 499.89 \\
\hline GR & & -5.2 & 493.95 & $0.0,490.58$ & $10.0,489.95$ & 15.7, & 489.86 \\
\hline GR & & 22.2 & 489.98 & $26.4,489.95$ & $30.7,489.73$ & 33.2, & 490.06 \\
\hline GR & & 37.2 , & 490.60 & $41.6,493.21$ & $43.6,495.68$ & 60.5 & 497.65 \\
\hline GR & & 75.9 & 497.21 & $139.8,497.49$ & $139.8,497.49$ & 170.1 & 499.71 \\
\hline $\begin{array}{l}\text { GR } \\
\star\end{array}$ & & 290.1 & 499.50 & $385.1,499.34$ & $409.6,500.41$ & 434.6 & 506.66 \\
\hline $\mathrm{N}$ & & 0.050 & 0 . & 0.045 & & & \\
\hline $\begin{array}{l}\text { SA } \\
*\end{array}$ & & & -14.6 & 43.6 & & & \\
\hline $\mathrm{HP}$ & 1 BRIDG & 495.21 & 1495.21 & & & & \\
\hline HP & 2 BRIDG & 495.21 & * * 1900 & & & & \\
\hline $\mathrm{HP}$ & $1 \mathrm{APPRO}$ & 496.69 & 1496.69 & & & & \\
\hline $\begin{array}{l}\mathrm{HP} \\
\star\end{array}$ & 2 APPRO & 496.69 & * * 1900 & & & & \\
\hline HP & 1 BRIDG & 496.61 & 1496.61 & & & & \\
\hline $\mathrm{HP}$ & 2 BRIDG & 496.61 & $* * 2664$ & & & & \\
\hline $\mathrm{HP}$ & 2 RDWAY & 500.17 & * * 188 & & & & \\
\hline $\mathrm{HP}$ & 1 APPRO & 500.17 & 1500.17 & & & & \\
\hline $\begin{array}{l}\mathrm{HP} \\
\star\end{array}$ & 2 APPRO & 500.17 & * * 2800 & & & & \\
\hline HP & 1 BRIDG & 496.61 & 1496.61 & & & & \\
\hline $\mathrm{HP}$ & 2 BRIDG & 496.61 & $* * 2560$ & & & & \\
\hline $\mathrm{HP}$ & 1 APPRO & 499.72 & 1499.72 & & & & \\
\hline & 2 APPRO & 499.72 & * * 2560 & & & & \\
\hline
\end{tabular}




\section{APPENDIX B: \\ WSPRO OUTPUT FILE}


WSPRO OUTPUT FILE

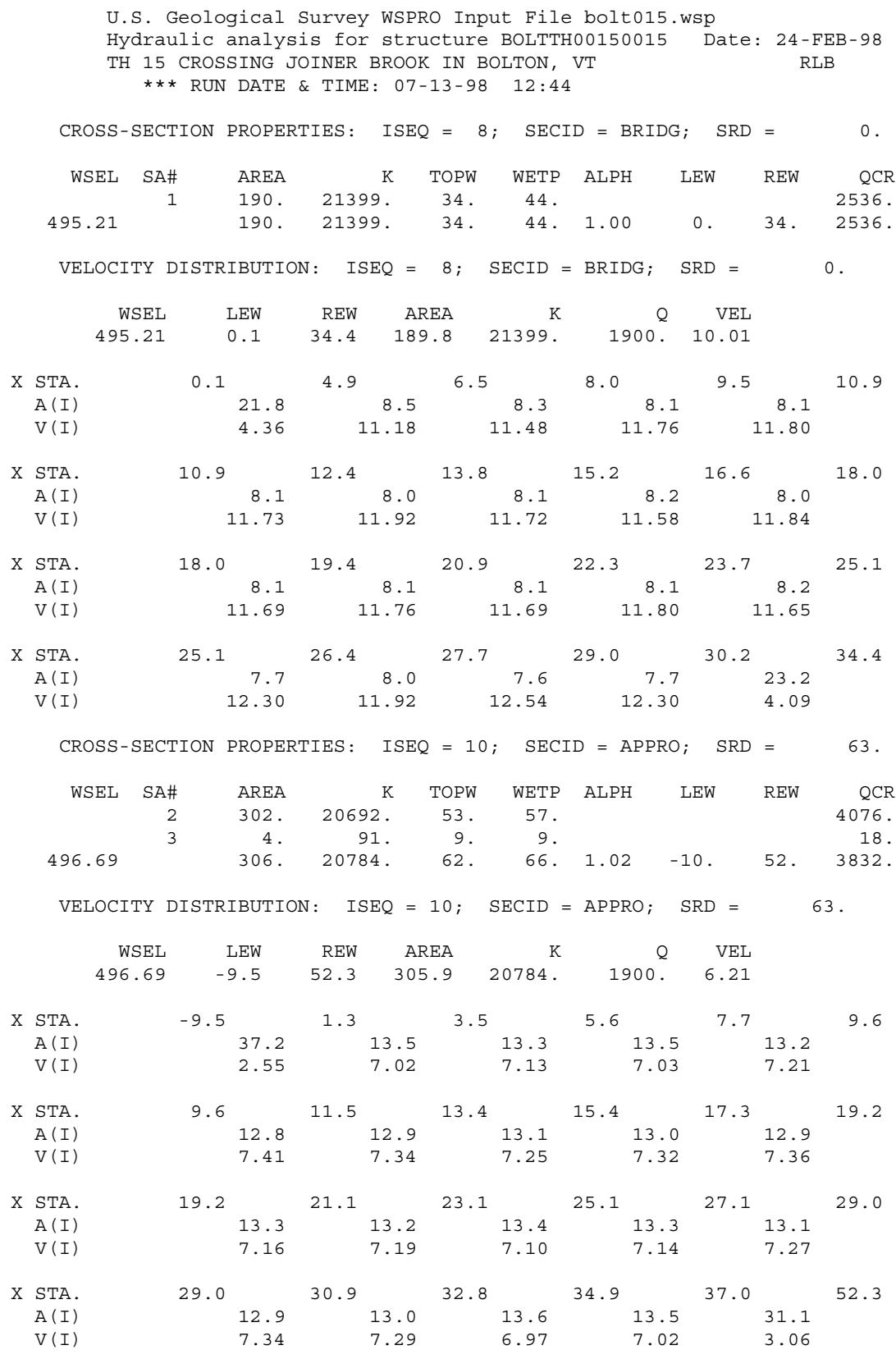


WSPRO OUTPUT FILE (continued)

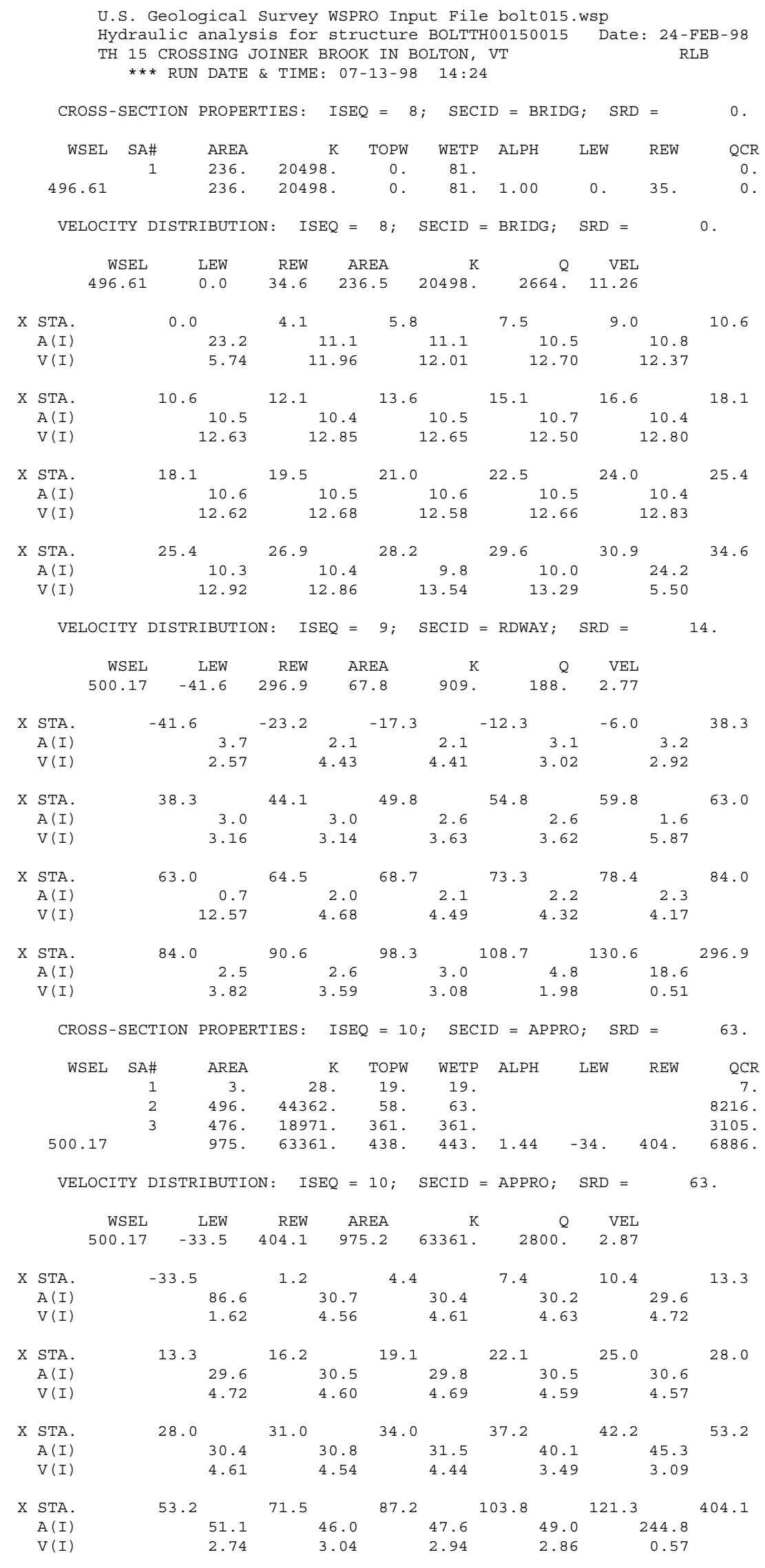


WSPRO OUTPUT FILE (continued)

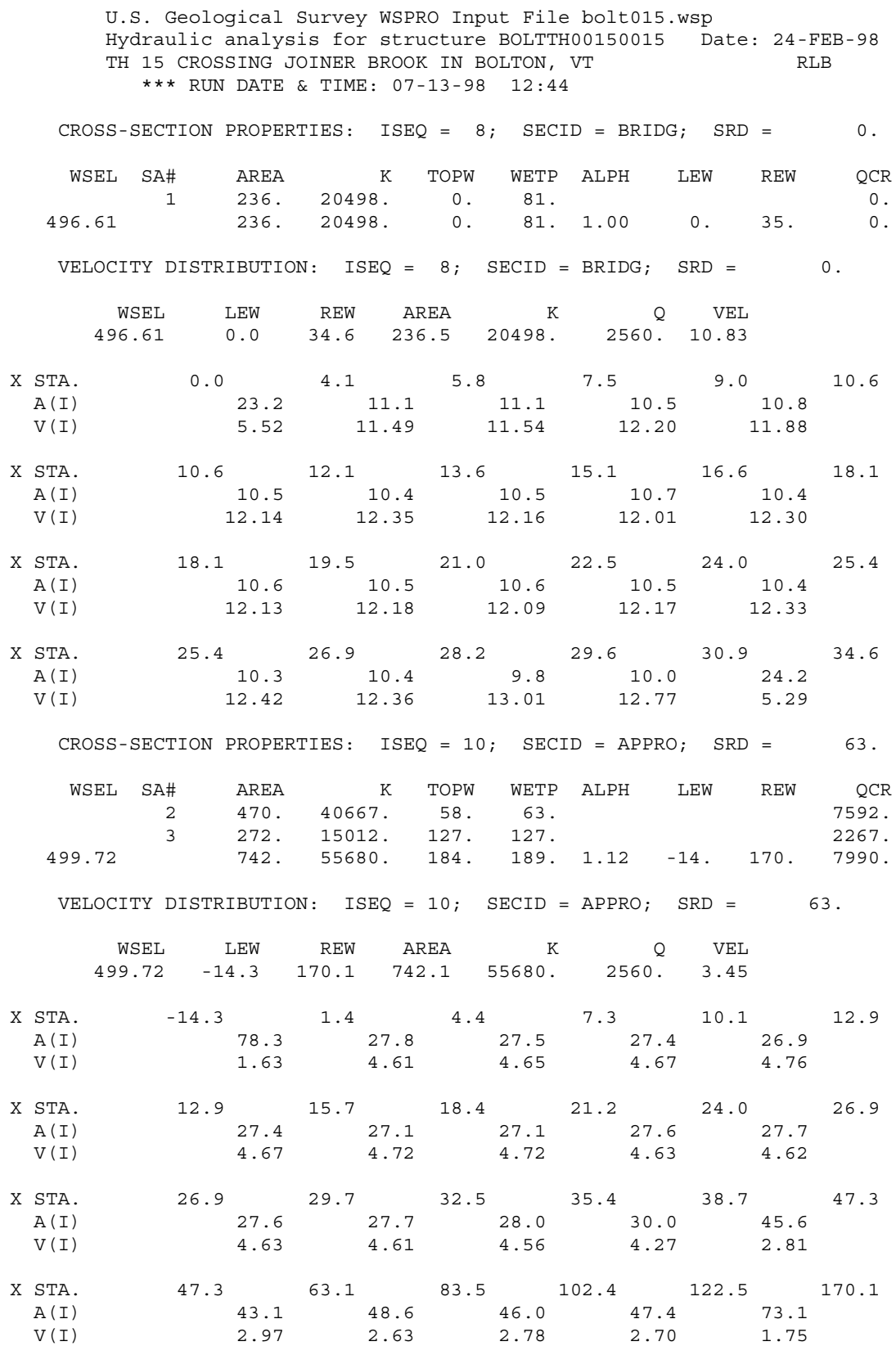


WSPRO OUTPUT FILE (continued)

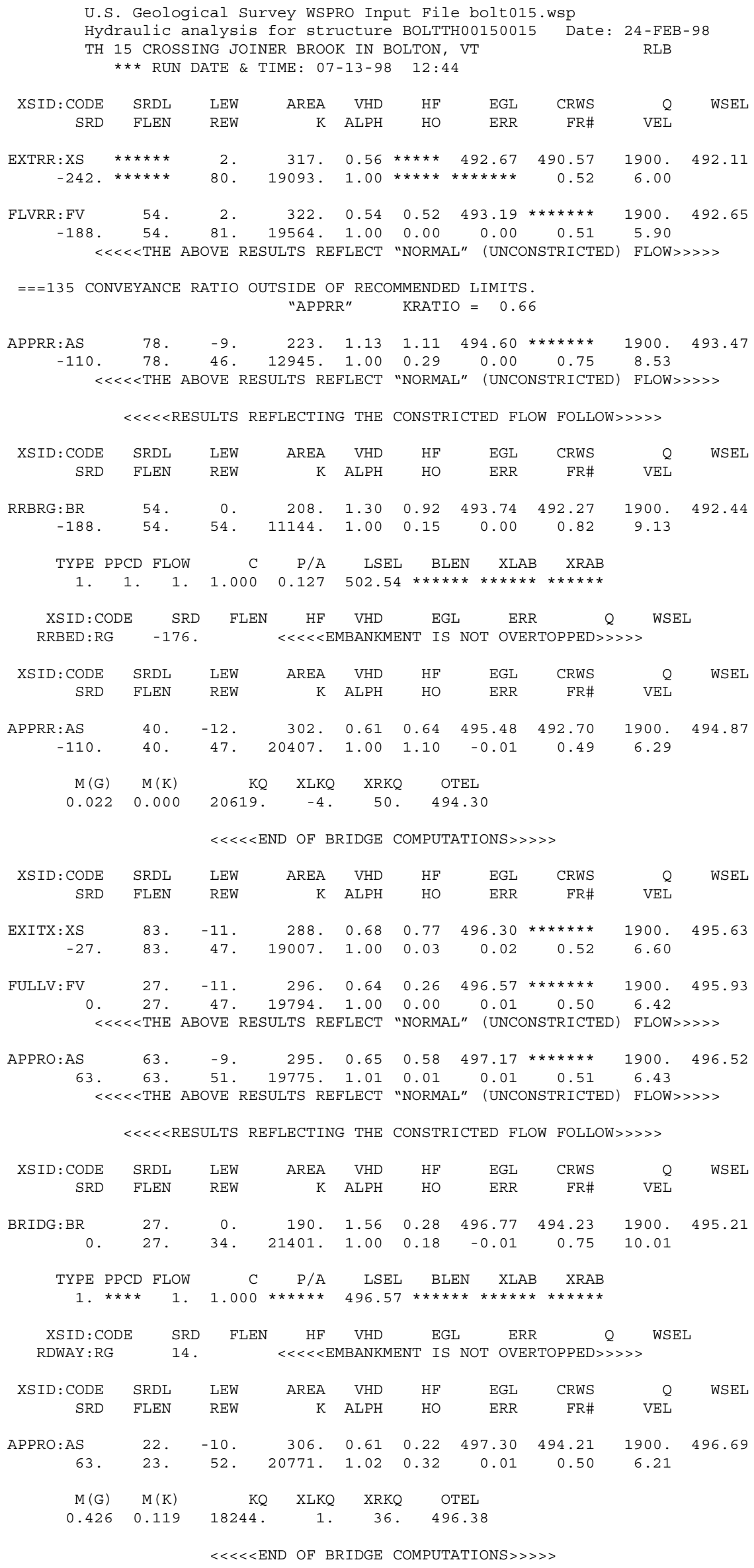


WSPRO OUTPUT FILE (continued)

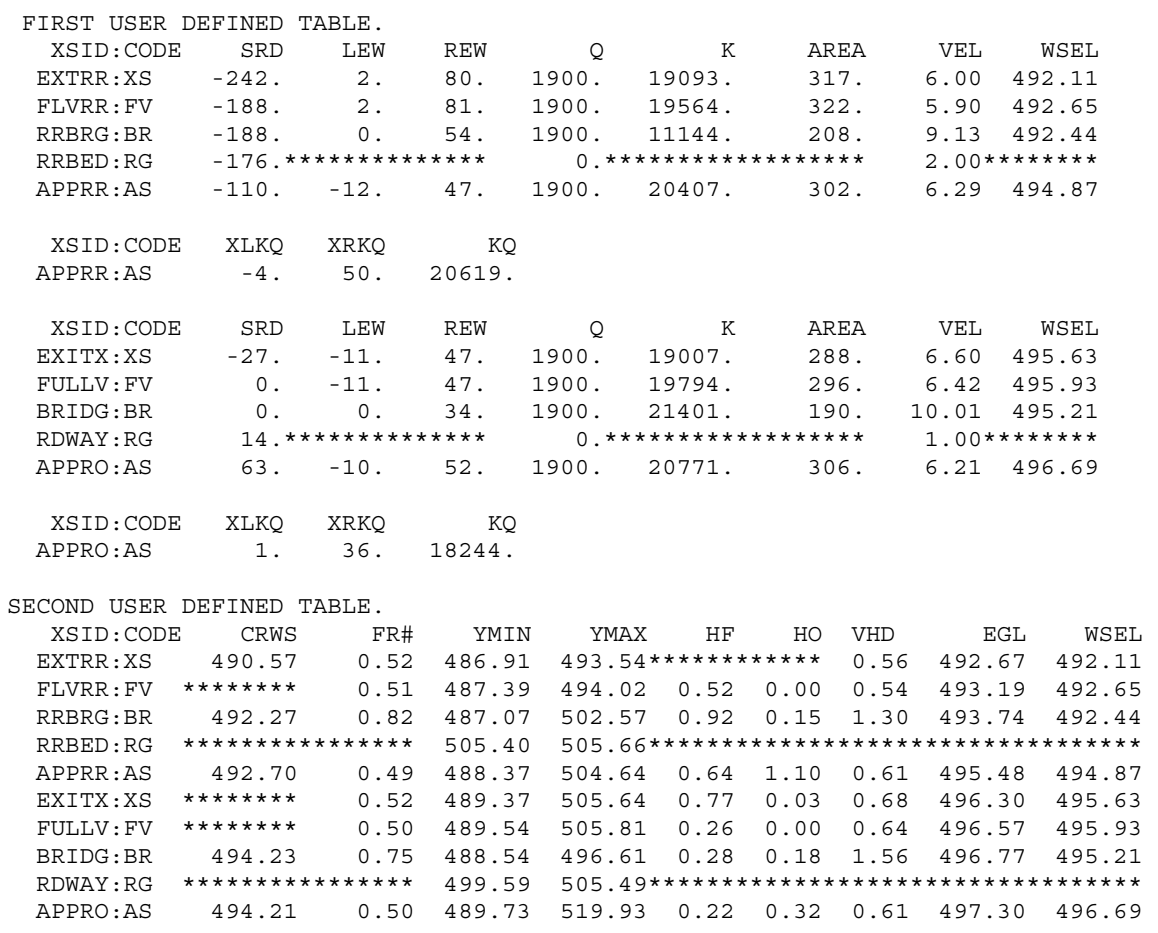


WSPRO OUTPUT FILE (continued)

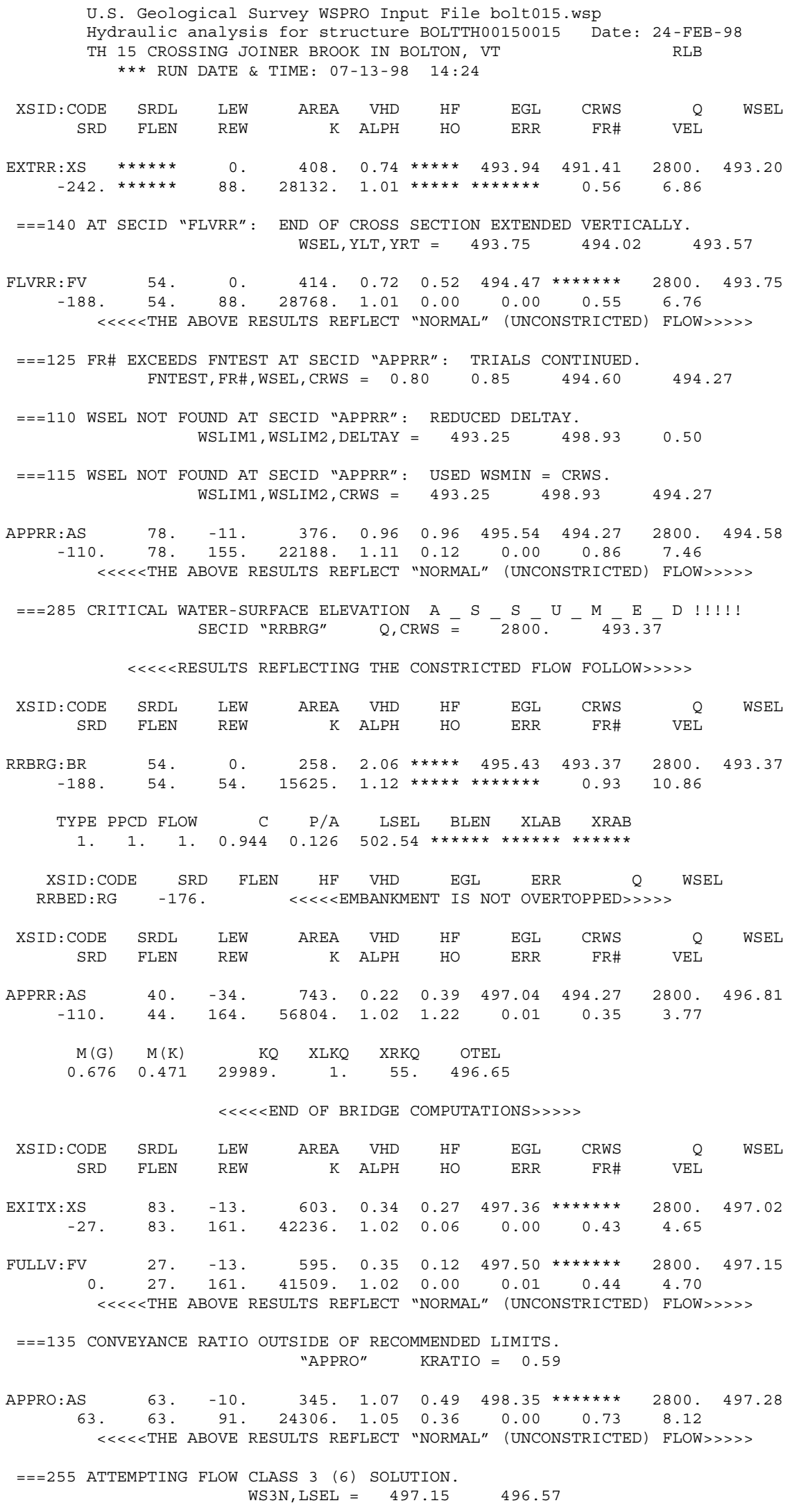


WSPRO OUTPUT FILE (continued)

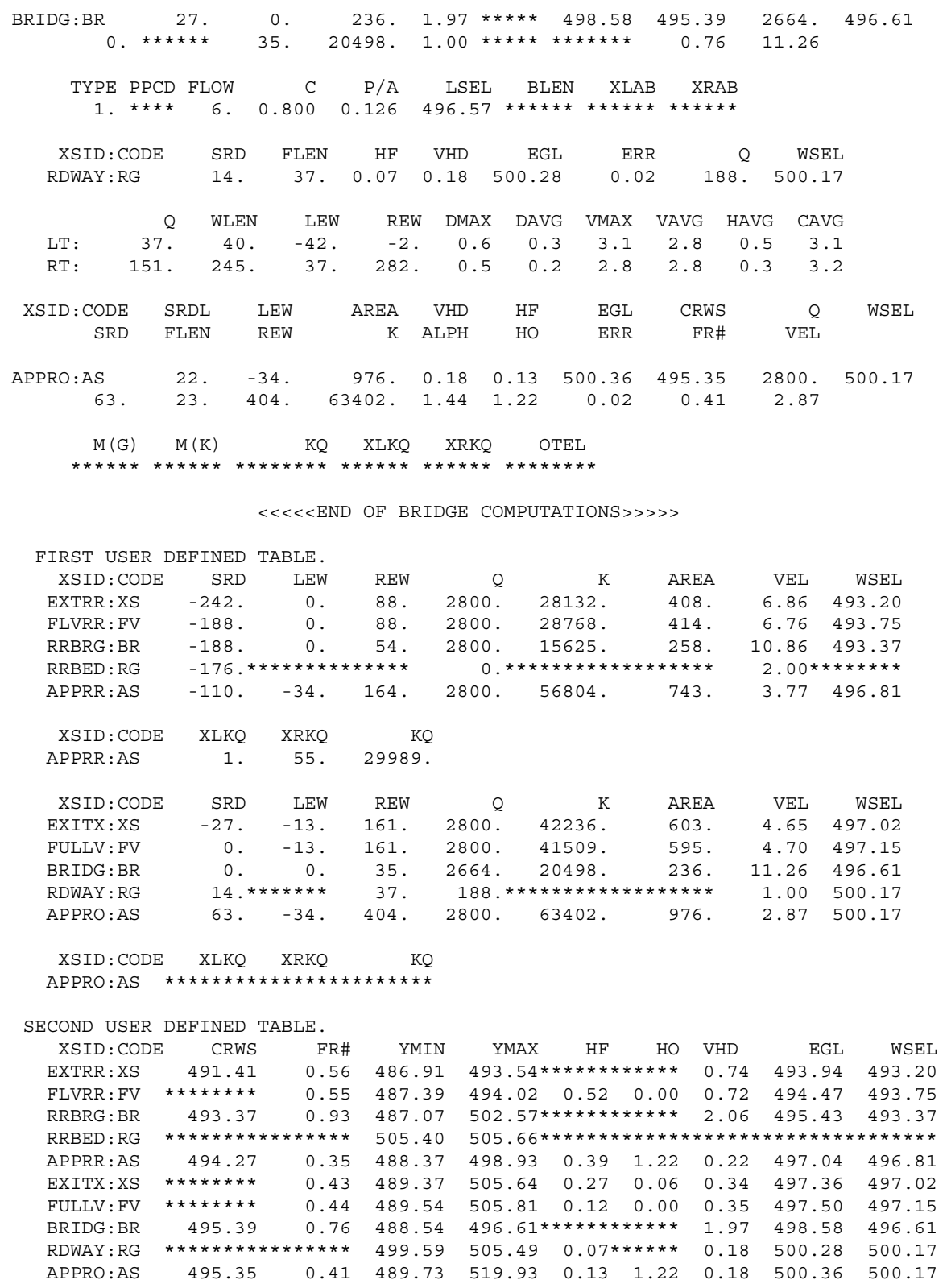


WSPRO OUTPUT FILE (continued)

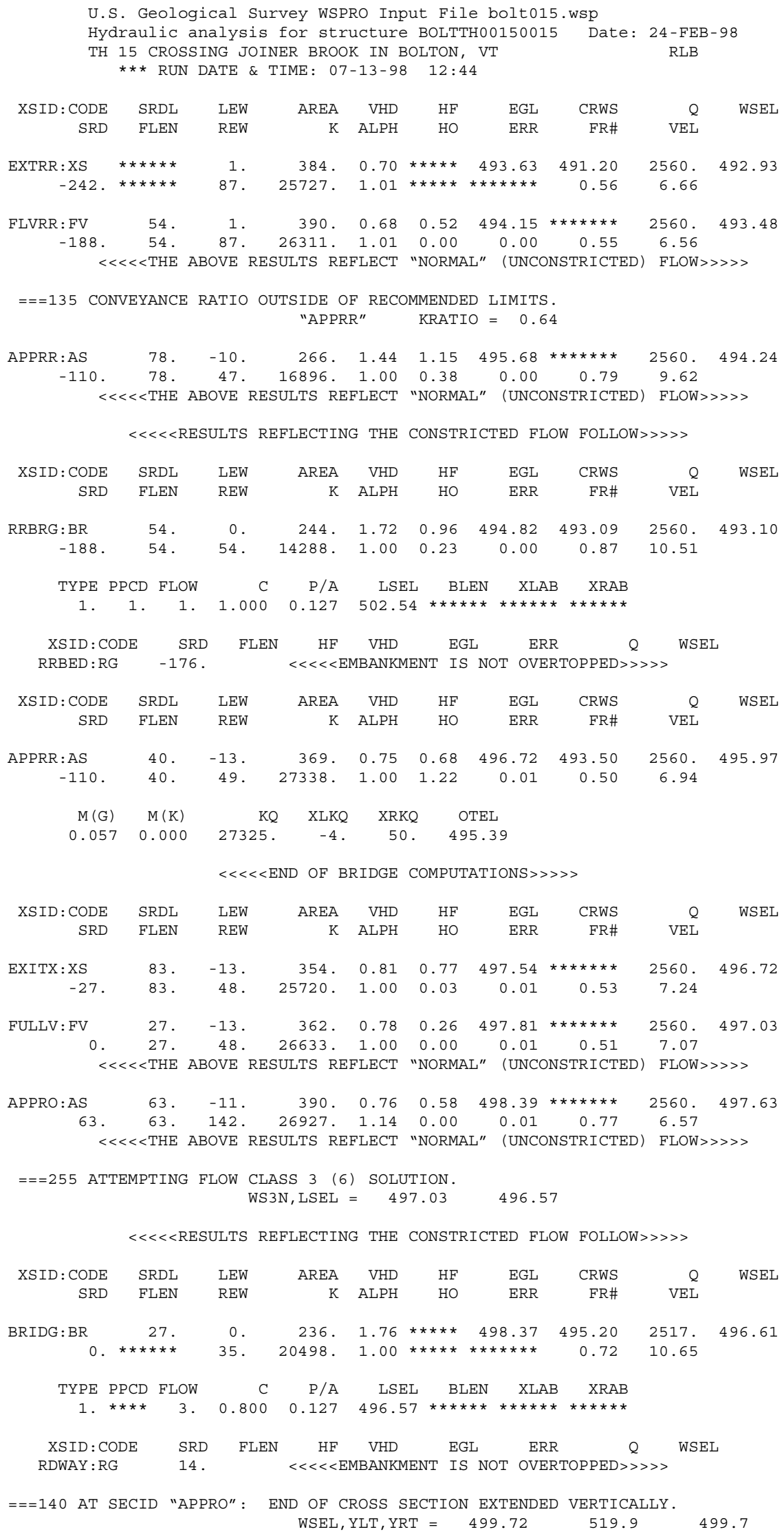


WSPRO OUTPUT FILE (continued)

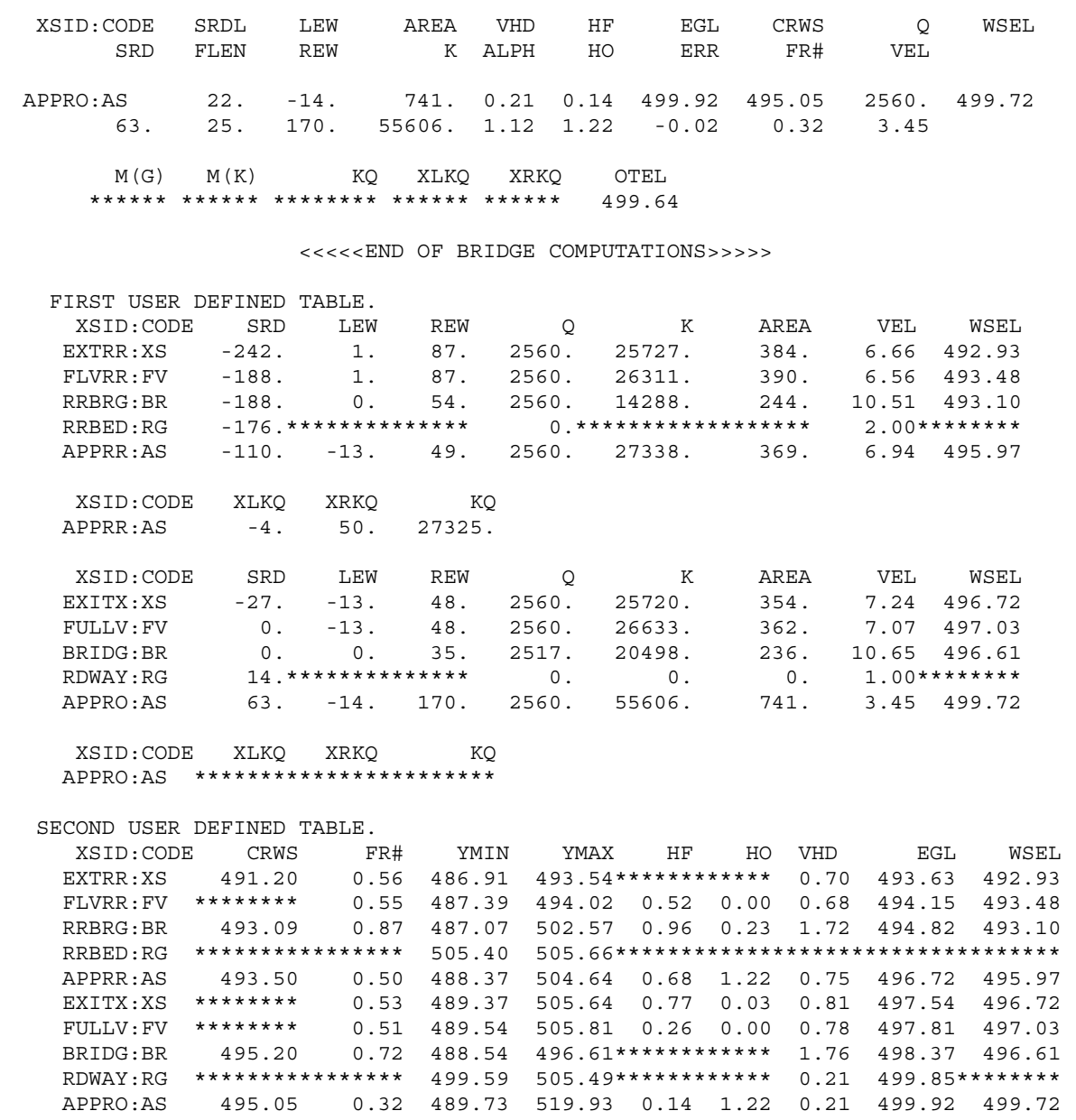




\section{APPENDIX C:}

\section{BED-MATERIAL PARTICLE-SIZE DISTRIBUTION}




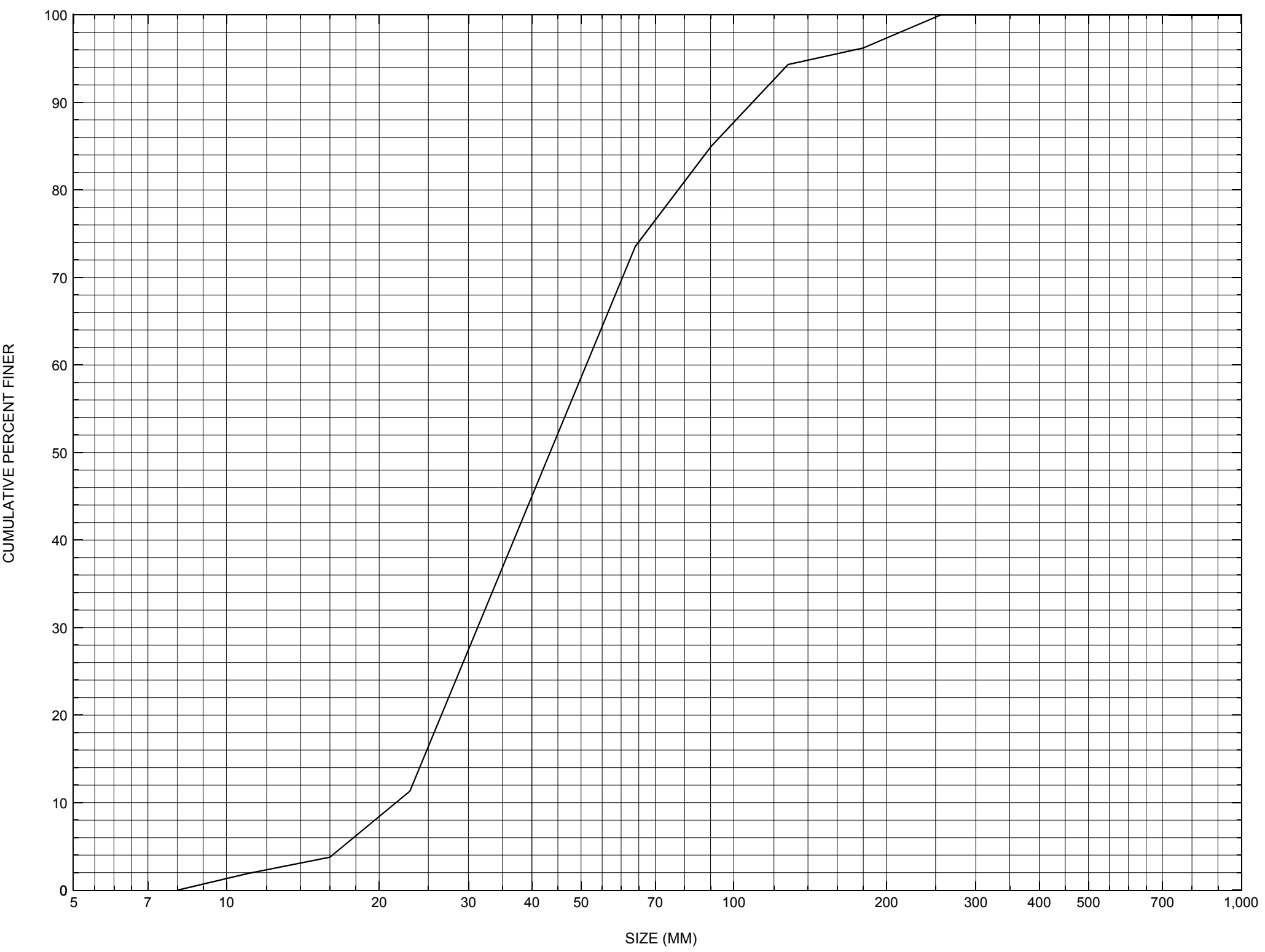

Appendix C. Bed material particle-size distribution for a pebble count in the channel approach of structure BOLTTH00150015, in Bolton, Vermont. 


\section{APPENDIX D: \\ HISTORICAL DATA FORM}




\section{Structure Number BOLTTH00150015}

\section{General Location Descriptive}

Data collected by (First Initial, Full last name) $\underline{\mathbf{L}}$. Medalie

Date $(M M / D D / Y Y) \_11 / 3 / \underline{95}$

Highway District Number $(I-2 ; n n) \underline{\mathbf{0 5}}$

Town (FIPS place code; I - 4; nnnnn)

Waterway (I - 6) JOINER BROOK

Route Number C3015

Topographic Map Huntington

Latitude (I - 16; nnnn.n) $\mathbf{4 4 2 2 4}$
County (FIPS county code; I - 3; nnn)

Mile marker (I - 11; nnn.nnn) $\mathbf{0 0 0 0 0 0}$

Road Name (I - 7): -

Vicinity (I - 9) 0.08 MI TO JCT W US2

Hydrologic Unit Code: $\underline{\mathbf{0 2 0 1 0 0 0 3}}$

Longitude (i - 17; nnnnn.n) $\mathbf{7 2 5 2 7}$

\section{Select Federal Inventory Codes}

FHWA Structure Number (I - 8) $\mathbf{1 0 0 4 0 1 0 0 1 5 0 4 0 1}$

Maintenance responsibility $(I-21 ; n n) \quad \mathbf{0 3}$

Year built (I - 27; YYYY) 1919

Average daily traffic, ADT (I - 29; nnnnnn) 000030

Year of ADT (I - 30; YY) $\mathbf{9 3}$

Opening skew to Roadway $(I-34 ; n n) \quad \mathbf{0 0}$

Operational status $(I-41 ; X) \underline{\mathbf{A}}$

Structure type (I - 43; nnn) 104

Approach span structure type $(I-44 ; n n n) \underline{\mathbf{0 0 0}}$

Number of spans (I - 45; nnn) $\mathbf{0 0 1}$

Number of approach spans (I - 46; nnnn) $\mathbf{0 0 0 0}$

Comments:

According to the structural inspection report dated 6/26/95, the structure is a concrete T-beam with an asphalt overlay. The abutments, wingwalls, and backwalls are concrete. Small sections of concrete footing are showing at the upstream end of the left abutment and at the upstream left wingwall and at the downstream end of the right abutment and at the downstream right wingwall. The abutments and wingwalls have a few fine cracks and small leaks overall. A few boulders are present around the ends of the wingwalls, and there are boulders along the US and DS channel embankments. The US-bridge-channel sketch shows a gravel bar near the left abutment.
Maximum span length (I - 48; nnnn) $\underline{\mathbf{0 0 3 6}}$

Structure length (I - 49; nnnnnn) $\underline{000039}$

Deck Width (I - 52; nn.n) 262

Channel \& Protection $(I-61 ; n) \underline{5}$

Waterway adequacy $(I-71 ; n) \underline{6}$

Underwater Inspection Frequency $(I-92 B ; X Y Y) \_$N

Year Reconstructed (I - 106) $\mathbf{0 0 0 0}$

Vertical clearance from streambed (nnn.n ft)

Waterway of full opening (nnn.n $\left.\mathrm{ft}^{2}\right)$
Clear span (nnn.n ft) 


\section{Bridge Hydrologic Data}

Is there hydrologic data available? $\underline{\mathbf{N}}$ if No, type ctrl- $n$ VTAOT Drainage area $\left(\mathrm{mi}^{2}\right)$ : -

Terrain character:

Stream character \& type: -

Streambed material: Gravel and stones

Discharge Data (cfs): $\quad Q_{2.33}-$

$$
\mathrm{Q}_{50}-
$$

Record flood date $(M M / D D / Y Y):-$

$\begin{array}{ll}Q_{10}- & Q_{25}- \\ Q_{100 \_-} & Q_{500-}-\end{array}$

Water surface elevation (ft): -

Estimated Discharge (cfs): Velocity at $\mathrm{Q}-$ $(\mathrm{ft} / \mathrm{s}):$

Ice conditions (Heavy, Moderate, Light) : -

Debris (Heavy, Moderate, Light):

The stage increases to maximum highwater elevation (Rapidly, Not rapidly):

The stream response is (Flashy, Not flashy):

Describe any significant site conditions upstream or downstream that may influence the stream's stage: -

Watershed storage area (in percent): - $\%$

The watershed storage area is: - _ (1-mainly at the headwaters; 2- uniformly distributed; 3-immediatly upstream oi the site)

Water Surface Elevation Estimates for Existing Structure:

\begin{tabular}{|l|l|l|l|l|l|}
\hline Peak discharge frequency & $Q_{2.33}$ & $Q_{10}$ & $Q_{25}$ & $Q_{50}$ & $Q_{100}$ \\
Water surface elevation (ft)) & - & - & - & - & - \\
Velocity $(\mathrm{ft} / \mathrm{sec})$ & - & - & - & - & - \\
\hline
\end{tabular}

Long term stream bed changes: -

Is the roadway overtopped below the $Q_{100}$ ? (Yes, No, Unknown):

Frequency: -

Relief Elevation $(f t)$ :

Discharge over roadway at $Q_{100}\left(f^{3} / \mathrm{sec}\right)$ :

Are there other structures nearby? (Yes, No, Unknown): If No or Unknown, type ctrl-n os Upstream distance (miles): Town: Year Built:

Highway No. : Structure No. : -

Clear span $(f t)$ : Clear Height (ft): Full Waterway $\left(f^{2}\right)$ : 
Downstream distance (miles): Town: Year Built:

Highway No. : Structure No. : Structure Type:

Clear span $(f t):$ Clear Height $(f t)$ : Full Waterway $\left(f^{2}\right):$

Comments:

\section{USGS Watershed Data}

Watershed Hydrographic Data

Drainage area $(D A)$

Watershed storage (ST)

Bridge site elevation $\mathbf{3 4 0}$ $\mathrm{mi}^{2}$ Lake/pond/swamp area $\mathrm{mi}^{2}$

Main channel length 6.1 $\mathrm{ft}$ $\%$ $10 \%$ channel length elevation $\mathbf{5 0 0}$ $\mathrm{ft} \quad 85 \%$ channel length elevation $\mathrm{ft}$

Main channel slope $(S)$

(S) $\mathrm{ft} / \mathrm{mi}$

Watershed Precipitation Data

Average site precipitation in Average headwater precipitation in

Maximum 2yr-24hr precipitation event $(124,2)$ in

Average seasonal snowfall (Sn) $\mathrm{ft}$ 


\section{Bridge Plan Data}

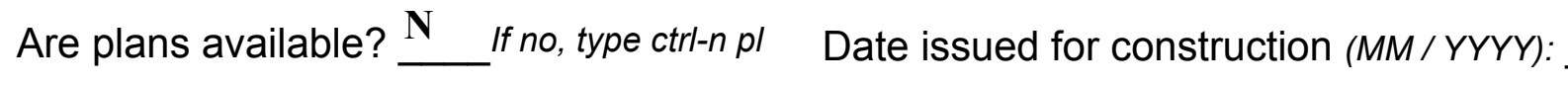

Project Number

Minimum channel bed elevation:

Low superstructure elevation: USLAB DSLAB USRAB DSRAB Benchmark location description:

NO BENCHMARK INFORMATION

Reference Point (MSL, Arbitrary, Other): Datum (NAD27, NAD83, Other):

Foundation Type: 4

If 1 : Footing Thickness

If 2: Pile Type:

If 3: Footing bottom elevation:

Is boring information available? $\mathbf{N}$

Foundation Material Type: $\mathbf{3}$

(1-Spreadfooting; 2-Pile; 3- Gravity; 4-Unknown)

Footing bottom elevation: -

Briefly describe material at foundation bottom elevation or around piles:

NO FOUNDATION MATERIAL INFORMATION 


\section{Cross-sectional Data}

Is cross-sectional data available? $\underline{\mathbf{Y}}$

If no, type ctrl-n xs

Source (FEMA, VTAOT, Other)? VTAOT

Comments: This cross section is the upstream face. The low chord elevations are from the survey log done for this report on $6 / 27 / 96$. The low chord to bed length data are from the sketch attached to a bridge inspection report dated 6/26/95. The sketch was done on 11/4/93.

\begin{tabular}{|c|c|c|c|c|c|c|c|c|c|c|c|}
\hline Station & $\mathbf{0}$ & 22.6 & 24.6 & 30.6 & 34.6 & - & - & - & - & - & - \\
\hline Feature & LAB & - & - & - & RAB & - & - & - & - & - & - \\
\hline $\begin{array}{l}\text { Low chord } \\
\text { elevation }\end{array}$ & 496.5 & 496.6 & 496.6 & 496.6 & 496.6 & - & - & - & - & - & - \\
\hline $\begin{array}{l}\text { Bed } \\
\text { elevation }\end{array}$ & 488.3 & 488.9 & 489.4 & 489.4 & 488.6 & - & - & - & - & - & - \\
\hline $\begin{array}{l}\text { Low chord } \\
\text { to bed }\end{array}$ & 8.2 & 7.7 & 7.2 & 7.2 & 8.0 & - & - & - & - & - & - \\
\hline Station & - & - & - & - & - & - & - & - & - & - & - \\
\hline Feature & - & - & - & - & - & - & - & - & - & - & - \\
\hline $\begin{array}{l}\text { Low chord } \\
\text { elevation }\end{array}$ & - & - & - & - & - & - & - & - & - & - & - \\
\hline $\begin{array}{l}\text { Bed } \\
\text { elevation }\end{array}$ & - & - & - & - & - & - & - & - & - & - & - \\
\hline $\begin{array}{l}\text { Low chord } \\
\text { to bed }\end{array}$ & - & - & - & - & - & - & - & - & - & - & - \\
\hline
\end{tabular}

Source (FEMA, VTAOT, Other)?

Comments: -

\begin{tabular}{|l|l|l|l|l|l|l|l|l|l|l|l|l|}
\hline Station & - & - & - & - & - & - & - & - & - & - & - \\
\hline Feature & - & - & - & - & - & - & - & - & - & - & - \\
\hline $\begin{array}{l}\text { Low chord } \\
\text { elevation }\end{array}$ & - & - & - & - & - & - & - & - & - & - & - \\
\hline $\begin{array}{l}\text { Bed } \\
\text { elevation }\end{array}$ & - & - & - & - & - & - & - & - & - & - & - \\
\hline $\begin{array}{l}\text { Low chord } \\
\text { to bed }\end{array}$ & - & - & - & - & - & - & - & - & - & - & - \\
\hline \begin{tabular}{l} 
Station \\
\hline Feature
\end{tabular} & - & - & - & - & - & - & - & - & - & - \\
\hline $\begin{array}{l}\text { Low chord } \\
\text { elevation }\end{array}$ & - & - & - & - & - & - & - & - & - & - \\
\hline $\begin{array}{l}\text { Bed } \\
\text { elevation }\end{array}$ & - & - & - & - & - & - & - & - & - & - \\
\hline $\begin{array}{l}\text { Low chord } \\
\text { to bed }\end{array}$ & - & - & - & - & - & - & - & - & - & - \\
\hline
\end{tabular}




\section{APPENDIX E: \\ LEVEL I DATA FORM}


U. S. Geological Survey

Bridge Field Data Collection and Processing Form

Qa/Qc Check by: MS

Date: $\underline{06 / 12 / 97}$

\section{Structure Number}

BOLTTH00150015

Computerized by: $\mathbf{M S}$ Date: $06 / 24 / 97$

Reviewd by: $\quad$ RB Date: $07 / 13 / 98$

\section{A. General Location Descriptive}

1. Data collected by (First Initial, Full last name) $\underline{\text { E. WILD }}$

2. Highway District Number $\mathbf{0 5}$

County CHITTENDEN (007)

Mile marker 000000

Waterway $(I-6)$ JOINER BROOK

Town BOLTON (06550)

Route Number $\mathbf{C 3 0 1 5}$

Road Name -

Hydrologic Unit Code: $\mathbf{0 2 0 1 0 0 0 3}$

3. Descriptive comments:

This bridge is located 0.08 miles from the junction with US 2 .

\section{B. Bridge Deck Observations}
4. Surface cover... LBUS 5
RBUS 4
LBDS 4
RBDS 4
Overall 4

(2b us, ds,lb,rb: 1- Urban; 2- Suburban; 3- Row crops; 4- Pasture; 5- Shrub- and brushland; 6- Forest; 7- Wetland)
5. Ambient water surface... US 2
UB 2
DS 2
(1- pool; 2- riffle)

6. Bridge structure type 1 (1- single span; 2- multiple span; 3- single arch; 4- multiple arch; 5-cylindrical culvert; 6- box culvert; or 7- other)
7. Bridge length $\mathbf{3 9}$
(feet)
Span length $\underline{\mathbf{3 6}}$
(feet)
Bridge width 26.2 (feet)

\section{Road approach to bridge:}
8. LB $\mathbf{0}$ RB $\mathbf{0}$
( 0 even, 1- lower, 2- higher)
9. LB
RB 1
(1- Paved, 2- Not paved)

10. Embankment slope (run / rise in feet / foot)

US left

US right

\begin{tabular}{|c|c|c|c|}
\hline \multicolumn{2}{|c|}{ Protection } & \multirow{2}{*}{ 13.Erosion } & 14.Severity \\
\hline 11.Type & 12.Cond. & $\mathbf{0}$ & $\mathbf{0}$ \\
\hline $\mathbf{1}$ & $\mathbf{1}$ & $\mathbf{0}$ & - \\
$\mathbf{0}$ & - & - & - \\
$\mathbf{0}$ & - & - & - \\
\hline $\mathbf{1}$ & $\mathbf{2}$ & $\mathbf{3}$ & $\mathbf{2}$ \\
\hline
\end{tabular}

Bank protection types: 0- none; 1- < 12 inches,

2- $<36$ inches; $3-<48$ inches;

4- < 60 inches; 5- wall / artificial levee

Bank protection conditions: 1- good; 2- slumped;

3- eroded; 4- failed

Erosion: 0 - none; 1- channel erosion; 2 -

road wash; 3- both; 4- other

Erosion Severity: 0 - none; 1- slight; 2- moderate; 3- severe

\section{Channel approach to bridge (BF):}

15. Angle of approach: $\mathbf{5}$

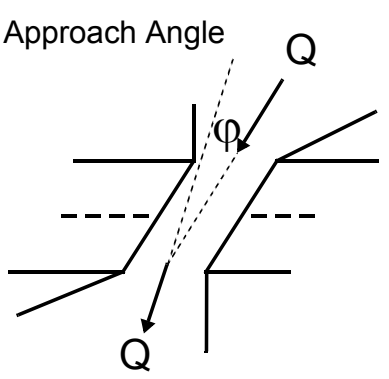

17. Channel impact zone 1 :

Where? RB (LB, RB)

Range? 94 feet US

Channel impact zone 2:

Where? LB $(L B, R B)$

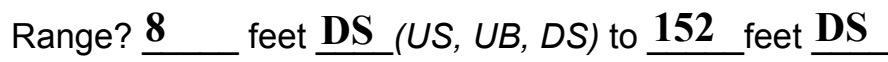

Impact Severity: 0- none to very slight; 1- Slight; 2- Moderate; 3- Severe
16. Bridge skew: 10 Bridge Skew Angle

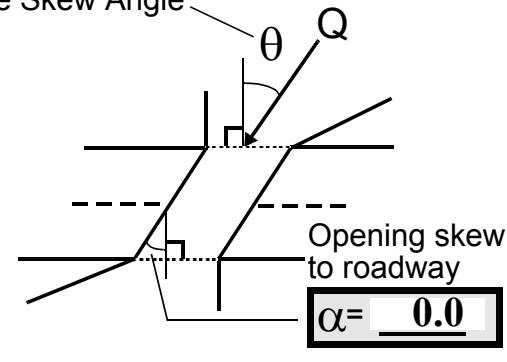

\section{Exist? $\mathbf{Y}(Y$ or $N)$}

Severity 2

US, UB, DS) to $\underline{\mathbf{0} \quad \text { feet } \underline{\mathbf{U B}}}$

Exist? $\mathbf{Y}(\mathrm{Y}$ or $N)$

Severity 1 
18. Bridge Type: 1a

1a- Vertical abutments with wingwalls

$1 \mathrm{~b}$ - Vertical abutments without wingwalls

2- Vertical abutments and wingwalls, sloping embankment Wingwalls parallel to abut. face

3- Spill through abutments

4- Sloping embankment, vertical wingwalls and abutments

Wingwall angle less than $90^{\circ}$.

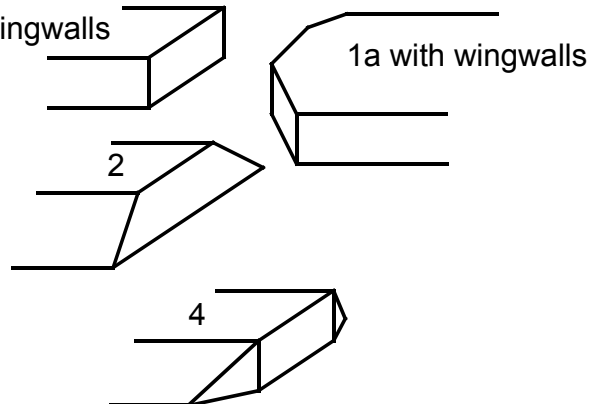

19. Bridge Deck Comments (surface cover variations, measured bridge and span lengths, bridge type variations, approach overflow width, etc.)

4. The US left bank surface cover is brush with a few trees along the bank. The DS left bank has trees along the bank, a lawn, and a medium size house. The US right bank has a few trees along the bank, grass, and one house. The DS right bank has trees along the bank, a large lawn and a house.

7. The measured deck width, bridge length, and span length are $25.82 \mathrm{ft}, 39 \mathrm{ft}$, and $36 \mathrm{ft}$, respectively. 17. Channel impact zone 1 has moderate impact severity due to lack of protection along the right bank. Channel impact zone 2 has low impact severity due to extensive protection on the left bank.

18. The DS left wingwall is parallel with the left abutment and can be considered type $1 \mathrm{~b}$.

\section{Upstream Channel Assessment}

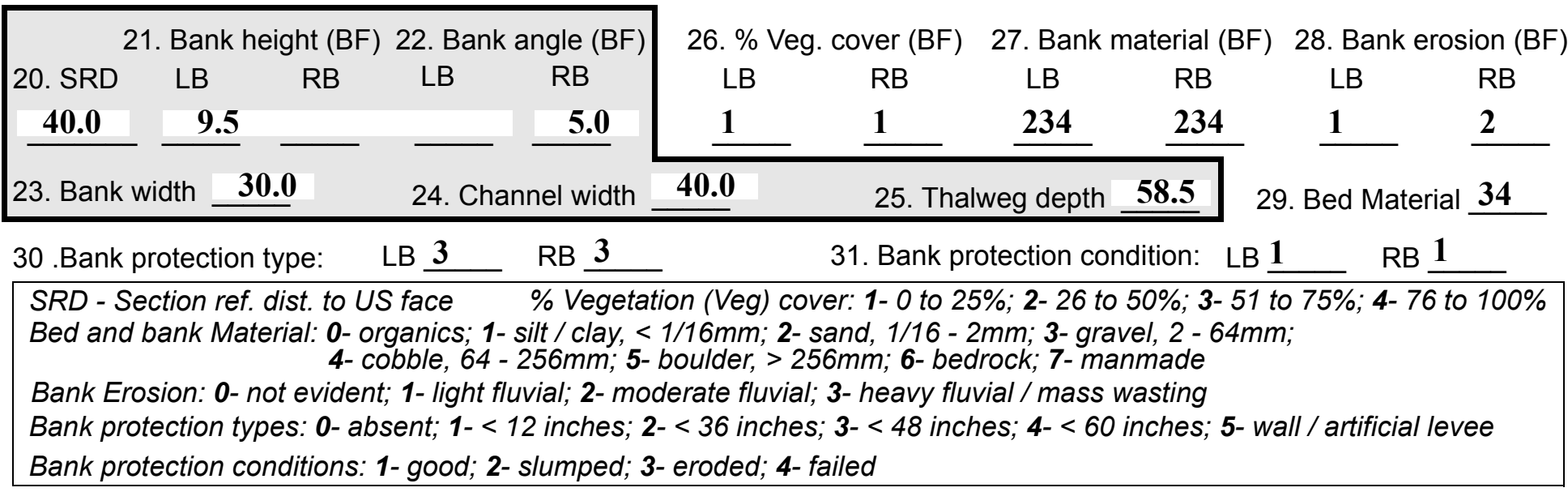

32. Comments (bank material variation, minor inflows, protection extent, etc.):

28. There is extensive erosion from $94 \mathrm{ft}$ US to $75 \mathrm{ft}$ US along the right bank.

30. The right bank protection extends from $114 \mathrm{ft}$ US to $94 \mathrm{ft}$ US. There is type 2 protection on the right bank that extends from $75 \mathrm{ft}$ US to $60 \mathrm{ft}$ US. The left bank protection extends from $114 \mathrm{ft}$ US to $57 \mathrm{ft}$ US. 

feet $\mathbf{U S}$ (US, UB) to $\mathbf{0}$ feet $\underline{\mathbf{U B}}$ (US, UB, DS) positioned 90 \%LB to $100 \%$ RB

37. Material: 3

38. Point or side bar comments (Circle Point or Side); Note additional bars, material variation, status, etc.):

There is an additional side bar located $42 \mathrm{ft}$ US to $3 \mathrm{ft}$ US. The mid-bar distance is $38 \mathrm{ft}$ US, the mid-bar width is $5.6 \mathrm{ft}$, and the material is gravel. There is a channel bar that has formed behind a boulder located $58.5 \mathrm{ft}$ US to $40.8 \mathrm{ft}$ US. It is comprised of gravel, the mid-bar distance is $53 \mathrm{ft}$ US, and the mid-bar width is $4.75 \mathrm{ft}$. It is positioned $50 \%$ LB to $80 \% \mathrm{RB}$.
39. Is a cut-bank present? Y
( $Y$ or if $N$ type ctrl-n cb)
40. Where? $\underline{\mathbf{R B}}(L B$ or $R B)$

41. Mid-bank distance: 25

42. Cut bank extent: 94

US, UB) to $\mathbf{0}$ feet $\underline{\mathbf{U B}}$ (US, UB, DS)

43. Bank damage: 1 (1- eroded and/or creep; 2- slip failure; 3- block failure)

44. Cut bank comments (eg. additional cut banks, protection condition, etc.):

\section{Is channel scour present? $\mathbf{Y}$ ( $Y$ or if $N$ type ctrl-n cs)}

\section{Scour dimensions: Length $\underline{\mathbf{1 2 . 5}}$ Width $\underline{\mathbf{4 . 7 5}}$ Depth : $\underline{\mathbf{1 . 5}} \quad$ Position $\underline{85} \%$ LB to $\underline{100} \%$ RB}

48. Scour comments (eg. additional scour areas, local scouring process, etc.):

The scour depth is $1.5 \mathrm{ft}$ assuming a $0.5 \mathrm{ft}$ thalweg. There is another scour hole located $65 \mathrm{ft}$ US to $30 \mathrm{ft}$ US. It is positioned between the right bank and the channel bar. The scour depth is $1 \mathrm{ft}$ assuming a $0.5 \mathrm{ft}$ thalweg. The position is $85 \%$ from the left bank to $95 \%$ right bank.

\section{Are there major confluences? $\mathbf{N}$}

51. Confluence 1: Distance Confluence 2: Distance 52. Enters on Enters on 54. Confluence comments (eg. confluence name):

\section{NO MAJOR CONFLUENCES}

50. How many? -
53. Type - (1-perennial; 2- ephemeral)
Type - (1-perennial; 2- ephemeral) ( $L B$ or $R B)$ (LB or $R B$ ) 46. Mid-scour distance: $\underline{25}$ 
65. Debris and Ice Is there debris accumulation?

67. Debris Potential $\underline{\mathbf{1}}$ ( 1- Low; 2- Moderate; 3- High)

69. Is there evidence of ice build-up? 2 (Y or $N)$

70. Debris and Ice Comments:

2
$(Y$ or $N)$ 66. Where? $\mathbf{Y}$

68. Capture Efficiency 2

(1- Upstream; 2- At bridge; 3- Both)

Ice Blockage Potential $\mathbf{N}$
(1- Low; 2- Moderate; 3- High)
(1-Low; 2- Moderate; 3- High)

\begin{tabular}{|l|c|c|c|c|c|c|c|c|}
\hline Abutments & $\begin{array}{c}\text { 71. Attack } \\
\angle \text { (BF) }\end{array}$ & $\begin{array}{c}\text { 72. Slope } \angle \\
\text { (Qmax) }\end{array}$ & $\begin{array}{c}\text { 73. Toe } \\
\text { loc. (BF) }\end{array}$ & $\begin{array}{c}\text { 74. Scour } \\
\text { Condition }\end{array}$ & $\begin{array}{c}75 . \text { Scour } \\
\text { depth }\end{array}$ & $\begin{array}{c}\text { 76. Exposure } \\
\text { depth }\end{array}$ & 77. Material & 78. Length \\
\hline LABUT & & $\mathbf{0}$ & $\mathbf{8 5}$ & $\mathbf{2}$ & $\mathbf{2}$ & $\mathbf{1 . 2}$ & $\mathbf{0 . 4}$ & $\mathbf{9 0 . 0}$ \\
\hline RABUT & $\mathbf{1}$ & $\mathbf{1 5}$ & $\mathbf{7 5}$ & & & $\mathbf{2}$ & $\mathbf{1}$ & $\mathbf{3 4 . 5}$ \\
\hline
\end{tabular}

Pushed: $L B$ or RB

Toe Location (Loc.): 0- even, 1- set back, 2- protrudes

Scour cond.: 0- not evident; 1- evident (comment); 2- footing exposed; 3-undermined footing; 4- piling exposed; 5- settled; 6- failed

Materials: 1- Concrete; 2- Stone masonry or drywall; 3- steel or metal; 4- wood

79. Abutment comments (eg. undermined penetration, unusual scour processes, debris, etc.):

1.5

0

1

74. The left abutment footing is exposed for $3.8 \mathrm{ft}$ (horizontally) at the US end.

75. The scour of the left abutment is located at the US end of the abutment. The scour of the right abutment is located at the DS end of the abutment.

80. Wingwalls:

$\begin{array}{lllll} & & & & \\ \text { Exist? Material? } & \text { Scour } & \text { Scour } & \text { Exposure } & \text { Angle? Length? } \\ & \text { Condition? depth? depth? } & & \end{array}$

USLWW:
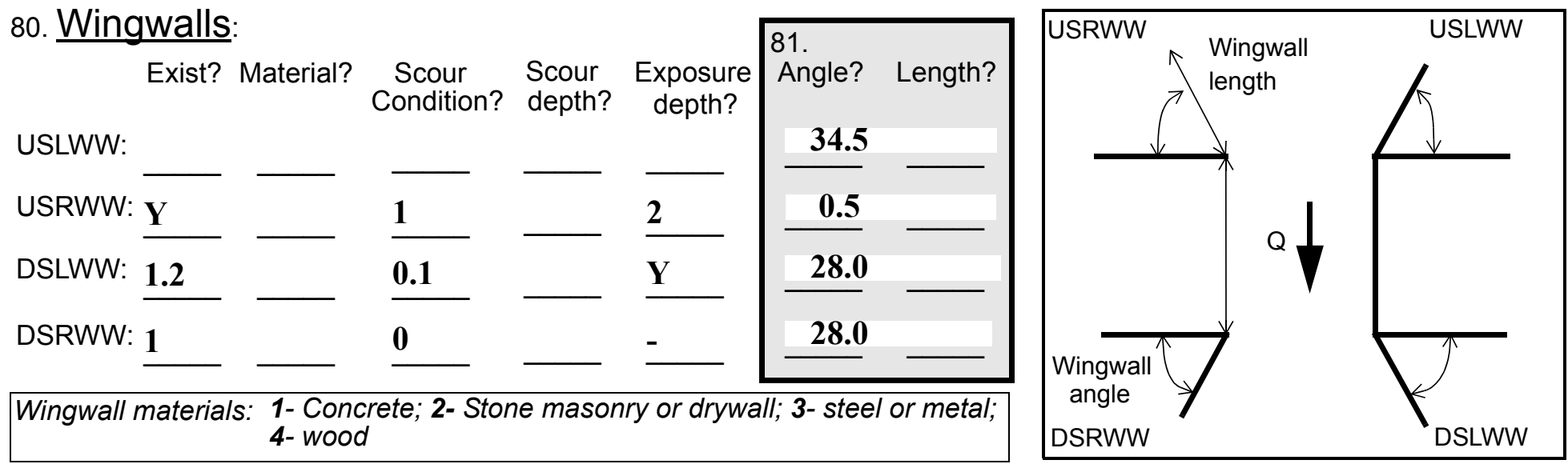

82. Bank / Bridge Protection:

\begin{tabular}{|l|l|l|l|l|l|l|c|c|}
\hline Location & USLWW & USRWW & LABUT & RABUT & LB & RB & DSLWW & DSRWW \\
\hline Type & - & $\mathbf{0}$ & $\mathbf{Y}$ & $\mathbf{1 . 5}$ & $\mathbf{1}$ & - & - & - \\
\hline Condition & $\mathbf{Y}$ & - & $\mathbf{1}$ & - & $\mathbf{2}$ & - & - & - \\
\hline Extent & $\mathbf{1}$ & - & $\mathbf{1}$ & $\mathbf{1}$ & $\mathbf{0}$ & $\mathbf{0}$ & $\mathbf{0}$ & - \\
\hline
\end{tabular}

Bank / Bridge protection types: 0- absent; 1- < 12 inches; 2- < 36 inches; 3- < 48 inches; 4- < 60 inches; 
83. Wingwall and protection comments (eg. undermined penetration, unusual scour processes, etc.):

-
-
-
-
-
0
-
-
1
1
3

\section{Piers:}

84. Are there piers? $\mathbf{8 0 .}$ ( $Y$ or if $N$ type ctrl-n pr)

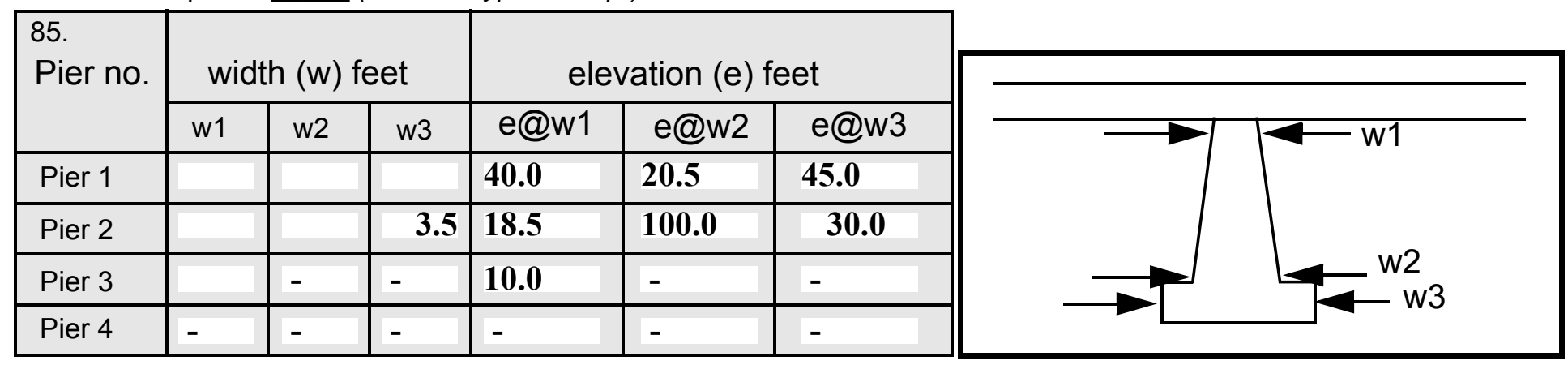

\begin{tabular}{|l|l|l|l|l|}
\hline Level 1 Pier Descr. & \multicolumn{1}{|c|}{1} & \multicolumn{1}{|c|}{2} & \multicolumn{1}{|c|}{3} & 4 \\
\hline 86. Location (BF) & The 1.2 & assum- & out 3.5 & \\
\hline 87. Type & ft & ing a & ft & \\
\hline 88. Material & scou & $\mathbf{0 . 5}$ & from & \\
\hline 89. Shape & r & thal- & the & \\
\hline 90. Inclined? & dept & weg. & left & \\
\hline 91. Attack $\angle$ (BF) & h on & The & abut & \\
\hline 92. Pushed & the & DS & ment & \\
\hline 93. Length (feet) & - & - & - & - \\
\hline 94. \# of piles & US & left & and & \\
\hline 95. Cross-members & left & wing & slope & \\
\hline 96. Scour Condition & wing & wall & s & N \\
\hline 97. Scour depth & wall & exte & dow & - \\
\hline 98. Exposure depth & is & nds & n. & - \\
\hline
\end{tabular}

LFP, LTB, LB, MCL, MCM, MCR, RB, RTB, RFP

1- Solid pier, 2- column, 3- bent

1-Wood; 2- concrete; 3- metal; 4- stone

1- Round; 2- Square; 3- Pointed

Y-yes; $N$ - no

$L B$ or $R B$

0- none; 1- laterals; 2- diagonals; 3- both

0- not evident; 1- evident (comment);

2- footing exposed; 3- piling exposed;

4- undermined footing; 5- settled; 6- failed 
99. Pier comments (eg. undermined penetration, protection and protection extent, unusual scour processes, etc.):

-
-
-
-
-
-
-
-
-
-

100.

\section{E. Downstream Channel Assessment}

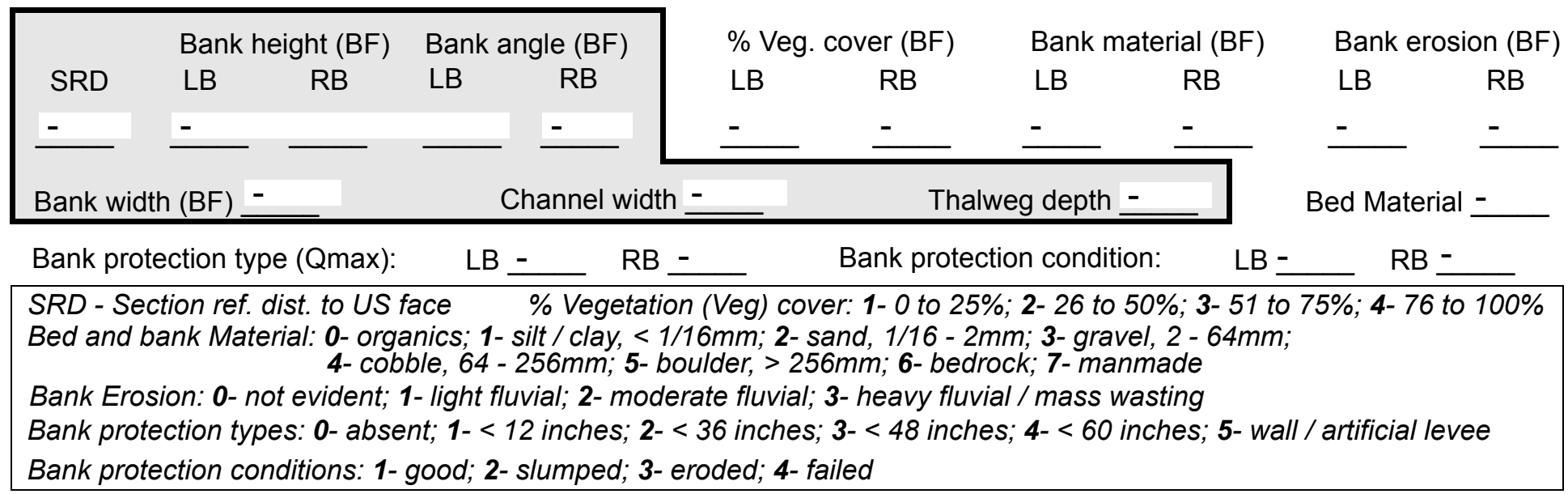

Comments (eg. bank material variation, minor inflows, protection extent, etc.):

$$
-
$$$$
-
$$$$
-
$$$$
-
$$$$
-
$$$$
-
$$$$
-
$$$$
-
$$

$-$

$-$

$-$

$-$

$-$

$-$

$-$

101. Is a drop structure present? _ _ ( or $N$, if $N$ type ctrl-n ds) 102. Distance: ___ feet 103. Drop: -_ feet 104. Structure material: ___ (1- steel sheet pile; 2- wood pile; 3- concrete; 4- other) 105. Drop structure comments (eg. downstream scour depth): 
106. Point/Side bar present? (Y or $N$. if $N$ type ctrl-n pb)Mid-bar distance:

Point bar extent: $\underline{\text { PIE }}$ feet $\underline{\mathbf{R S}}$ (US, UB, DS) to feet (US, UB, DS) positioned $\%$ LB to $\%$ RB

Material:

Point or side bar comments (Circle Point or Side; note additional bars, material variation, status, etc.):

$\underline{\text { Is a cut-bank present? }} \underline{\mathbf{2}}$ (Y or if $N$ type ctrl-n cb) Where? $\underline{\mathbf{2}}$ (LB or RB) Mid-bank distance: $\underline{\mathbf{2 3}}$ Cut bank extent: $\underline{23}$ feet $\underline{2}$ (US, UB, DS) to $\underline{2}$ feet $\underline{34}$ (US, UB, DS)

Bank damage: 2 (1- eroded and/or creep; 2- slip failure; 3- block failure)

Cut bank comments (eg. additional cut banks, protection condition, etc.): o

1

The left bank protection extends from $32 \mathrm{ft}$ DS to $152 \mathrm{ft}$ DS.

Is channel scour present? A (Y or if N type ctrl-n cs) Mid-scour distance: rail-

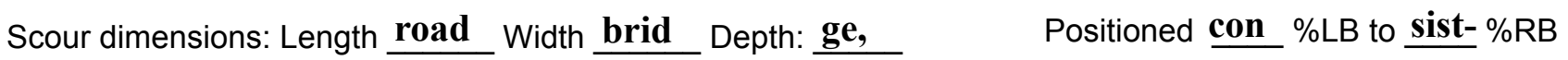

Scour comments (eg. additional scour areas, local scouring process, etc.):

ing of five piers each with six piles, is located $191 \mathrm{ft}$ DS of this bridge.

Are there major confluences? Confluence 1: Distance Confluence 2: Distance

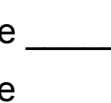

Confluence comments (eg. confluence name): (Y or if $N$ type ctrl-n $m c)$ Enters on ( $L B$ or $R B)$ (LB or $R B)$
How many?

Type (1- perennial; 2- ephemeral)

Type (1-perennial; 2- ephemeral)

\section{F. Geomorphic Channel Assessment}

107. Stage of reach evolution $\mathbf{N}$
1- Constructed

2- Stable

3- Aggraded

4- Degraded

5- Laterally unstable

6- Vertically and laterally unstable 
108. Evolution comments (Channel evolution not considering bridge effects; See HEC-20, Figure 1 for geomorphic descriptors):

-

NO DROP STRUCTURE

Y

16

5.4

9.5

UB

36 


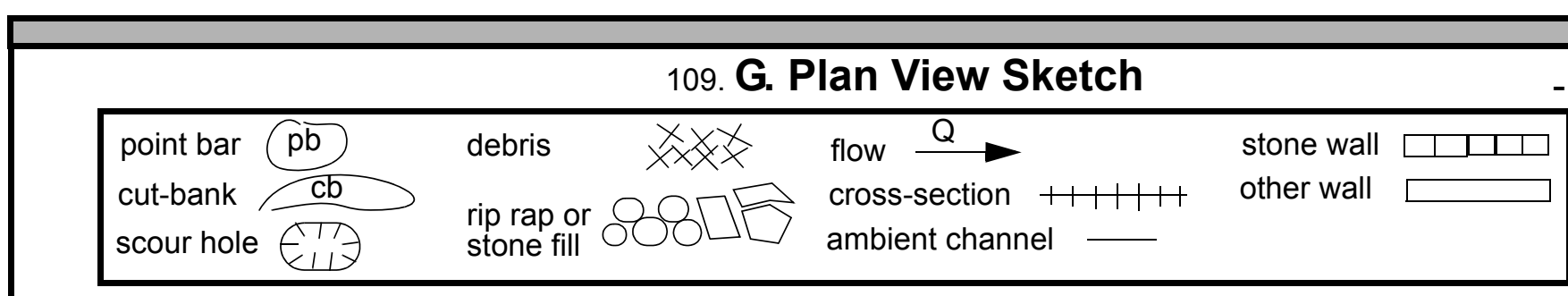

D

cut-bank

scour hole rip rap or
stone fill cross-section $+1+1+1$ ambient channe other wall 
APPENDIX F:

SCOUR COMPUTATIONS 


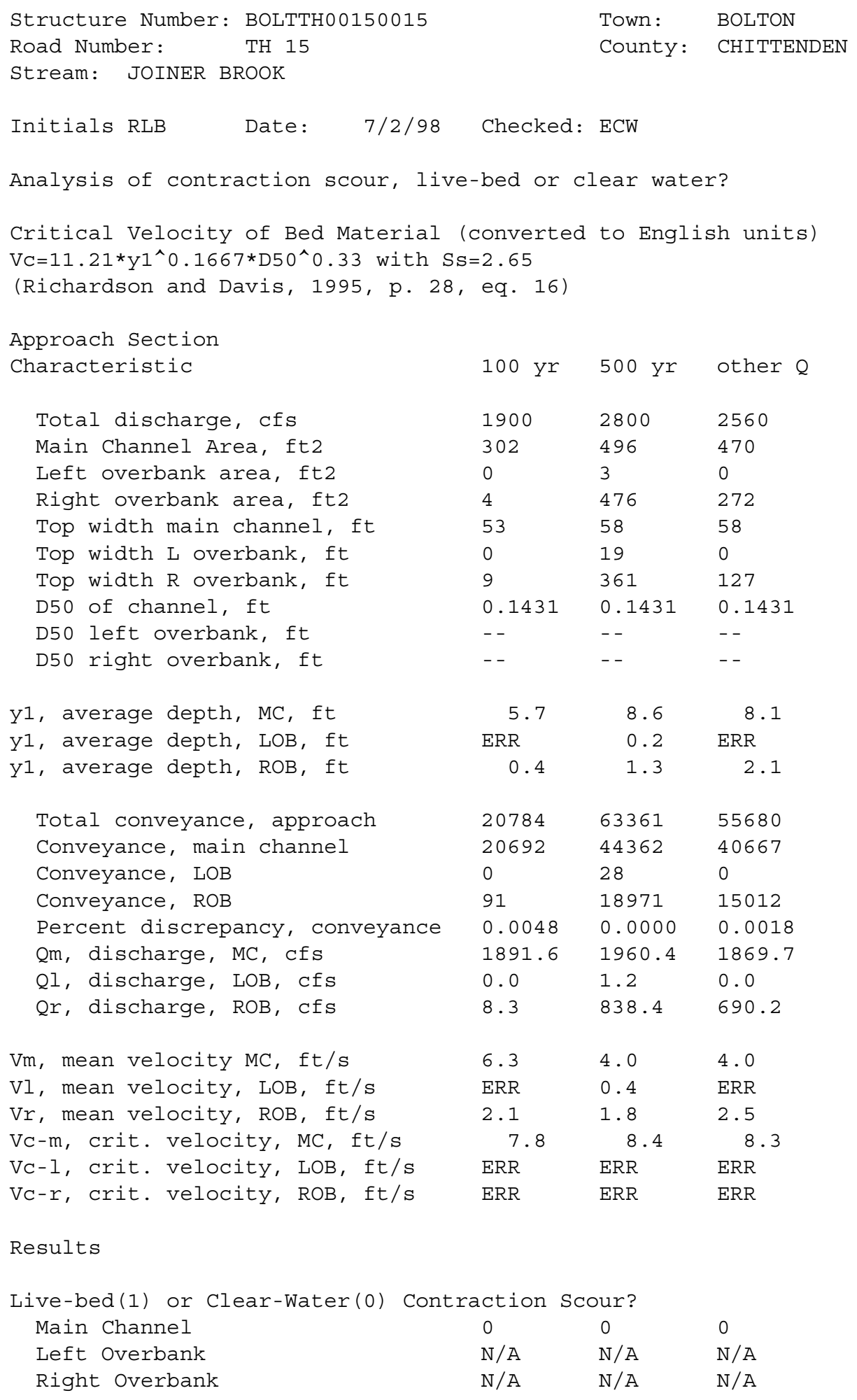


Clear water Contraction Scour in MAIN CHANNEL

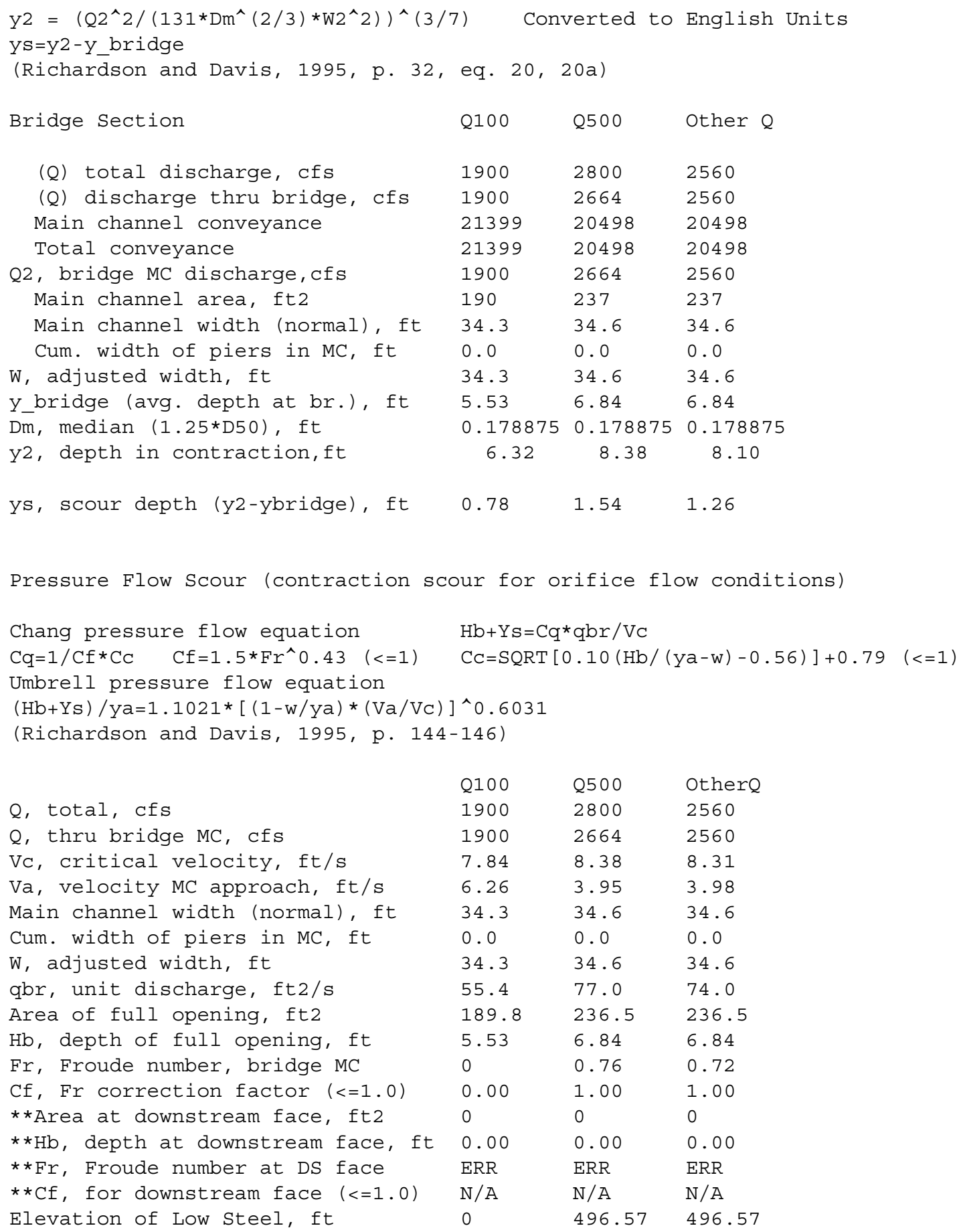


Elevation of Bed, ft

Elevation of Approach, ft

Friction loss, approach, ft

Elevation of WS immediately US, ft

ya, depth immediately US, ft

Mean elevation of deck, ft

w, depth of overflow, ft $(>=0)$

0.00

$*{ }^{*} \mathrm{CC}$, for downstream face $(<=1.0)$ ERR

Ys, scour w/Chang equation, ft

Ys, scour w/Umbrell equation, ft
$-5.53$

$\begin{array}{lll}0 & 0.13 & 0.14\end{array}$

$0.00 \quad 500.04 \quad 499.58$

$\begin{array}{lll}5.53 & 10.31 & 9.85\end{array}$

$0 \quad 500.62 \quad 500.62$

$0.00 \quad 0.00 \quad 0.00$

$0.89 \quad 0.91$

ERR ERR

$\begin{array}{lll}\mathrm{N} / \mathrm{A} & 3.46 & 2.99\end{array}$

$\begin{array}{lll}\mathrm{N} / \mathrm{A} & 0.38 & 0.12\end{array}$

**=for UNsubmerged orifice flow using estimated downstream bridge face properties.

**Ys, scour w/Chang equation, ft N/A ERR ERR

**Ys, scour w/Umbrell equation, ft ERR $7.22 \quad 6.96$

\begin{tabular}{|c|c|c|c|}
\hline \multirow{2}{*}{\multicolumn{4}{|c|}{$\begin{array}{l}\mathrm{DC}=\left[\left(1.94 * \mathrm{~V}^{\wedge} 2\right) /(5.75 * \log (12.27 * \mathrm{Y} / \mathrm{D} 90))^{\wedge} 2\right] /[0.03 *(165-62.4)] \\
\text { Depth to Armoring }=3 *(1 / \mathrm{PC}-1) \\
\text { (Federal Highway Administration, 1993) }\end{array}$}} \\
\hline & & & \\
\hline \multirow{3}{*}{$\begin{array}{l}\text { Downstream bridge face property } \\
\text { Q, discharge thru bridge MC, cfs } \\
\text { Main channel area (DS), ft2 }\end{array}$} & $100-y r$ & $500-y r$ & Other $Q$ \\
\hline & 1900 & 2664 & 2560 \\
\hline & 189.8 & 236.5 & 236.5 \\
\hline Main channel width (normal), ft & 34.3 & 34.6 & 34.6 \\
\hline Cum. width of piers, ft & 0.0 & 0.0 & 0.0 \\
\hline Adj. main channel width, ft & 34.3 & 34.6 & 34.6 \\
\hline D90, ft & 0.3571 & 0.3571 & 0.3571 \\
\hline D95, ft & 0.4732 & 0.4732 & 0.4732 \\
\hline Dc, critical grain size, ft & 0.3678 & 0.4303 & 0.3974 \\
\hline Pc, Decimal percent coarser than Dc & 0.092 & 0.055 & 0.071 \\
\hline Depth to armoring, ft & 10.89 & 22.18 & 15.60 \\
\hline
\end{tabular}

Abutment Scour

Froehlich's Abutment Scour

$\mathrm{Ys} / \mathrm{Y} 1=2.27 * \mathrm{~K} 1 * \mathrm{~K} 2 *\left(\mathrm{a}^{\prime} / \mathrm{Y} 1\right)^{\wedge} 0.43 * \mathrm{Fr} 1^{\wedge} 0.61+1$

(Richardson and Davis, 1995, p. 48, eq. 28)

Characteristic

Left Abutment

Right Abutment

$100 \mathrm{yr} Q 500 \mathrm{yr} Q$ Other Q $100 \mathrm{yr}$ Q $500 \mathrm{yr} \mathrm{Q}$ Other Q

\begin{tabular}{|c|c|c|c|c|c|c|}
\hline (Qt), total dis & 1900 & 2800 & 2560 & 1900 & 2800 & 2560 \\
\hline a', abut.length blocking flow, ft & 9.6 & 33.5 & 14.3 & 17.9 & 369.5 & \\
\hline area of blocked flow ft 2 & 33.07 & 73.95 & 71.32 & 47.84 & 495.8 & \\
\hline discharge blocked abut. cf & 84.44 & - - & 116.59 & 212.62 & - - & \\
\hline
\end{tabular}

(If using Qtotal overbank to obtain Ve, leave Qe blank and enter Ve and Fr manually)

$\begin{array}{lllllll}\text { Ve, }(\mathrm{Qe} / \mathrm{Ae}), \mathrm{ft} / \mathrm{s} & 2.55 & 1.62 & 1.63 & 4.44 & 1.99 & 2.73 \\ \mathrm{ya}, \text { depth of } \mathrm{f} / \mathrm{p} \text { flow, ft } & 3.44 & 2.21 & 4.99 & 2.67 & 1.34 & 2.52\end{array}$

--Coeff., K1, for abut. type (1.0, verti.; 0.82, verti. w/ wingwall; 0.55, spillthru)

$\begin{array}{lllllll}\text { K1 } & 0.82 & 0.82 & 0.82 & 0.82 & 0.82 & 0.82\end{array}$

--Angle (theta) of embankment (<90 if abut. points DS; >90 if abut. points US) 


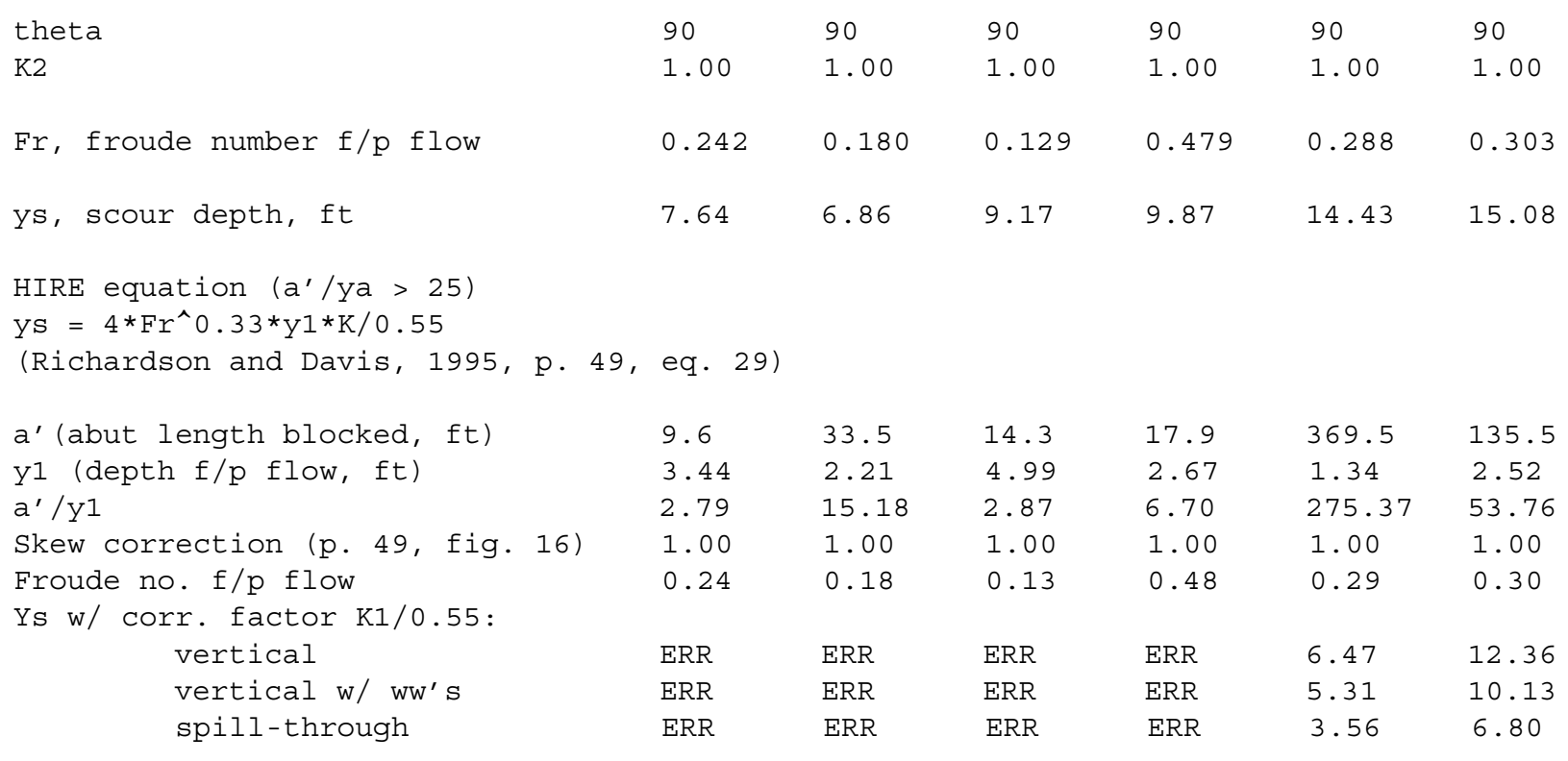

Abutment riprap Sizing

Isbash Relationship

$\mathrm{D} 50=\mathrm{Y} * \mathrm{~K} * \mathrm{Fr} \wedge 2 /(\mathrm{Ss}-1)$ and $\mathrm{D} 50=\mathrm{Y} * \mathrm{~K} *\left(\mathrm{Fr} r^{\wedge} 2\right)^{\wedge} 0.14 /(\mathrm{Ss}-1)$

(Richardson and Davis, 1995, p112, eq. 81,82)

\begin{tabular}{|c|c|c|c|c|c|c|}
\hline Characteristic & Q100 & Q500 & Other $\mathrm{Q}$ & Q100 & Q500 & Other Q \\
\hline Fr, Froude Number & 0.75 & 0.76 & 0.72 & 0.75 & 0.76 & 0.72 \\
\hline$y$, depth of flow in bridge, ft & 5.53 & 6.84 & 6.84 & 5.53 & 6.84 & 6.84 \\
\hline Median stone Diameter for ripra & $\therefore$ left & outment & & right & abutment & ft \\
\hline Fr<=0.8 (vertical abut.) & 1.92 & 2.44 & 2.19 & 1.92 & 2.44 & 2.19 \\
\hline Fr>0.8 (vertical abut.) & ERR & ERR & ERR & ERR & ERR & ERR \\
\hline
\end{tabular}


